\title{
A Survey and Ecological Risk Assessment of Niclosamide and Its Degradation Intermediate in Wucheng Waters within Poyang Lake Basin, China
}

\author{
Qiang Yang1,2, Miao Liu ${ }^{1,2}$, Donggen Huang ${ }^{1,2 *}$, Wei Xiong ${ }^{1,2}$, Qianli Yu ${ }^{1,2}$, \\ Tao Guo ${ }^{1,2}$, Qi Wei ${ }^{1,2}$
}

'Key Laboratory of Poyang Lake Environment and Resource Utilization, Nanchang University, Nanchang, China ${ }^{2}$ School of Environmental and Chemical Engineering, Nanchang University, Nanchang, China

Received: 18 December 2019

Accepted: 30 January 2020

\begin{abstract}
Long-term use of niclosamide (NCL) in schistosomiasis control areas may have a certain impact on the regional ecological environment. The purpose of this study is to investigate the NCL residue and its possible degradation intermediates in the Wucheng water in the Poyang Lake Basin of China, and assess its ecological risks. Water samples were collected at twelve sites every month from July 2017 to June 2018, the collected samples were qualitatively and quantitatively analyzed by HPLC and HPLC/MS techniques, and regional ecotoxicological risks were estimated by calculating risk quotients (RQ). The results indicated that due to the use of NCL, the regional water environment contained NCL, 2-chloro-4-nitroaniline, 5-chlorosalicylic acid and 2,5-dihydroxybenzoic acid, etc, and their concentrations were $0.000 \sim 0.028 \mu \mathrm{g} / \mathrm{L}, 0.000 \sim 0.015 \mu \mathrm{g} / \mathrm{L}, 0.000 \sim 0.019 \mu \mathrm{g} / \mathrm{L}$, below detectable limit, respectively. The mixed risk quotient (MRQ) for sensitive aquatic organisms algae, invertebrates and fish was $0.000 \sim 0.707,0.000 \sim 0.864,0.000 \sim 0.935$, respectively. These findings demonstrated that the mixture of NCL residues and their intermediates has a moderate risk to sensitive aquatic organisms such as algae, invertebrates and fish in Wucheng waters. In order to protect the regional water environment, it is necessary to strengthen the supervision and management work after the application of NCL drugs.
\end{abstract}

Keywords: survey, risk assessment, niclosamide residue, risk quotients, Wucheng water environment

*e-mail: dghuang1017@163.com 


\section{Introduction}

Niclosamide, 5-chloro-N-(2-chloro-4-nitrophenyl)2-hydroxybenzamide is the most important component of control programs for the freshwater snails that serve as intermediate hosts for the trematodes causing schistosomiasis [1-3] and fascioliasis in humans and domestic animals in many tropical and subtropical countries [4]. In China's schistosomiasi control area, NCL is used to kill snails and schistosomiasis, repel human and animal mites, and the annual usage exceeds 3,200 tons [5] After being used in the application site, NCL does not use any effective technical means for treatment, and discharged arbitrarily, which has a serious impact on the regional ecological environment [6].

The molecular structure of niclosamide is a halogenated phenolic organic substance with a vapor pressure of $9.9^{*} 10^{-9} \mathrm{~mm} \mathrm{Hg}\left(20^{\circ} \mathrm{C}\right)$ and a solubility of $0.1 \mathrm{mg} / \mathrm{L}\left(20^{\circ} \mathrm{C}\right)$ in water. It is a typical polar/ionizable ion. The group $(-\mathrm{OH})$ of halogenated phenolic organic is easy to remain in the environmental solid medium and has high bioaccumulation [7]. For freshwater invertebrates, NCL is a highly toxic substance $\left(\mathrm{EC}_{50} 0.034 \rightarrow 50 \mathrm{mg} / \mathrm{L}\right)$, a highly toxic substance for freshwater fish $\left(\mathrm{LC}_{50} 0.03 \rightarrow 0.23 \mathrm{mg} / \mathrm{L}\right)$, and a toxic substance for aquatic plants $\left(\mathrm{EC}_{50} \quad 0.04 \rightarrow 1450 \mathrm{mg} / \mathrm{L}\right)$ [8]. It has a great influence on algae, invertebrates and freshwater fish in schistosomiasis control areas.

In the natural environment composed of watersuspended particulate matter-sediment, NCL is preferentially adsorbed in solid phase media such as suspended solids and sediment. Under the action of sunlight, plants, microorganisms, etc, NCL migrates and transforms. In the aqueous phase, NCL ionizes the ionization of the group - $\mathrm{OH}$, making NCL molecular and ionic. Under sunlight, NCL undergoes rapid photolysis in the surface waters [9, 10]; Microbial degradation of NCL under the action of aerobic or anaerobic microorganisms [11]; Plant and its root exudates cause migration and transformation of NCL in water-sediment-plant systems [12]. The intermediates of NCL degradation in the natural environment are mainly 5-chlorosalicylic acid, 2-chloro-4-nitroaniline, etc. [13-15], which have higher biological toxicity than the parent compound and have DNA damage effect [16].

In order to study the possible impact on the regional ecological environment after the use of NCL, we conducted a one-year survey and analysis of the water bodies in the lakes and rivers around Wucheng, Poyang Lake Basin, China, selecting 12 sampling points and collecting samples on the $15^{\text {th }}$ of each month. The collected samples were qualitatively and quantitatively analyzed by using HPLC and HPLC/MS techniques, and ecological risk quotients to evaluate the ecological risk of the regional water environment.

\section{Materials and Methods}

\author{
Chemicals
}

5 -chloro-N-(2-chloro-4-nitrophenyl)-2hydroxybenzamide [Niclosamide, Analytical reagent, (AR)], 2-chloro-4-nitroaniline (AR), 5-chlorosalicylic acid (AR), 2,5-dihydroxybenzoic acid (AR) were purchased from Sigma-Aldrich (Germany). Ultrapure water was obtained from a Milli-Q system (Millipore, China) and chromatography grade solvents (formic acid and methanol) for HPLC, HPLC/MS were obtained from Sigma-Aldrich (Germany).

\section{Study Area}

Wucheng is a town with a long history located in the northeast of Yongxiu County, Jiujiang City, Jiangxi Province. It covers an area of 356 square kilometers, with a population of 15160 and a block area of 2.5 square kilometers at the intersection of Ganjiang River, Xiushui River and Poyang Lake. Wucheng town has $2.7 * 10^{9} \mathrm{~m}^{2}$ of water surface, $1.3 * 10^{8} \mathrm{~m}^{2}$ of grassland and 42 lakes of different sizes. It is known as the "migrant bird paradise" and is a world-class natural reservation. It is a typical subtropical monsoon climate: The average annual temperature here is $16-17^{\circ} \mathrm{C}$, and the annual precipitation is $1300-1600 \mathrm{~mm}$, more than $40 \%$ of which is concentrated in the second quarter. During the rainy season from early summer to June and July, the rainfall is concentrated, heavy rains are frequent. The average annual precipitation in May and June is about $200 \mathrm{~mm}$, which can easily lead to floods; After the rainy season, the weather is hot and dry because it is controlled by the subtropical high pressure. In many years, the high-temperature is higher than 35 degrees Celsius in more than 20 days; Autumn temperatures are milder and there is less rain; Winter is cold but frost is short. Wucheng is the largest market and administrative center of the Poyang Lake Reservation, at the same time, it is the core area of schistosomiasis control in China, the annual use of NCL in this region is about 20 tons.

\section{Field Sampling}

In this study, 12 sampling points (See Fig. 1 and Table S1) were selected in Wucheng Town for a field sampling analysis every other month for a period from July 2017 to June 2018. The sampling point is $3 \sim 5 \mathrm{~m}$ from the shore and the water depth is $0.2 \sim 0.5$ $\mathrm{m}$. After cleaning the sampler and the brown sampling bottle with the on-site water sample, the water samples are collected according to the sampling standard and saved in number. The survey area includes 7 lakes (site $1 \# \sim 7 \#$ ) and 2 rivers (site $8 \# \sim 12 \#$ ), of which site $5 \#$ and site $7 \#$ select the side closer to the residential area, and other lake sampling points are located away from the 


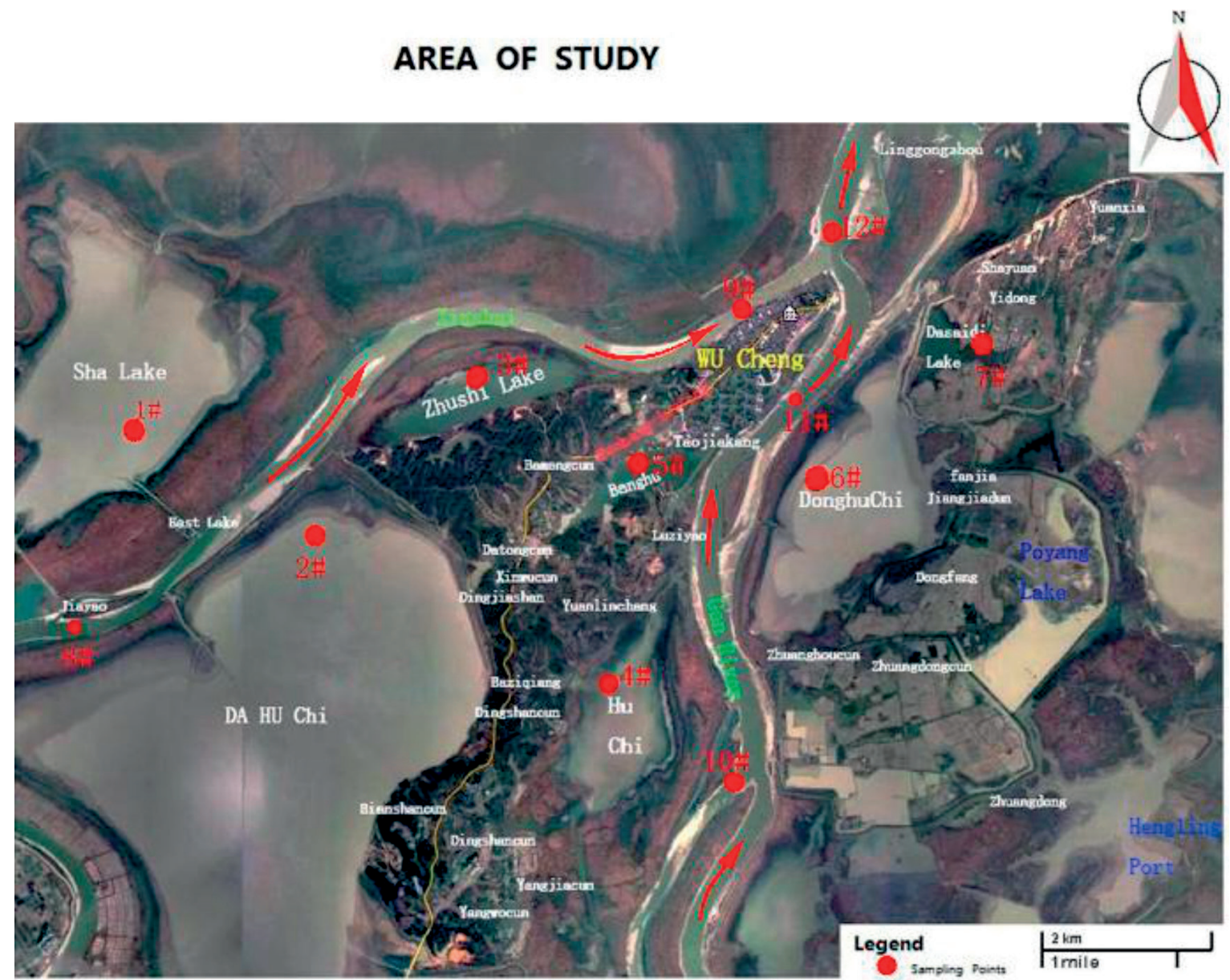

Fig. 1. Map of selected sampling locations in the Wucheng River Basin.

grass beach (molluscicides sparging area) on the near side of the spraying area, the upstream and downstream spacing of the river sampling point is about $8 \mathrm{~km}$, and the $12 \#$ sampling point located in the intersection of Xiushui and Ganjiang River. The samples were transported to the laboratory and stored at $4^{\circ} \mathrm{C}$. Detailed information about the coordinates and physicochemical properties of samples was given in Table S2.

Table S1. Coordinates and altitude of the selected sites on Wucheng.

\begin{tabular}{|c|c|c|c|c|}
\hline Site No. & Location & Longitude & Latitudes & Altitude \\
\hline Site 1\# & Sha Lake & $115^{\circ} 56^{\prime} 15.0^{\prime \prime} \mathrm{E}$ & $29^{\circ} 10^{\prime} 13.3^{\prime \prime} \mathrm{N}$ & 14.89 \\
\hline Site 2\# & Da hu Chi & $115^{\circ} 57^{\prime} 16.7^{\prime \prime} \mathrm{E}$ & $29^{\circ} 09^{\prime} 18.6^{\prime \prime} \mathrm{N}$ & 15.27 \\
\hline Site 3\# & Zhu shi Lake & $115^{\circ} 59^{\prime} 05.8^{\prime \prime} \mathrm{E}$ & $29^{\circ} 10^{\prime} 35.8^{\prime \prime} \mathrm{N}$ & 14.02 \\
\hline Site 4\# & Hu Chi & $115^{\circ} 59^{\prime} 50.7^{\prime \prime} \mathrm{E}$ & $29^{\circ} 08^{\prime} 28.9^{\prime \prime} \mathrm{N}$ & 14.61 \\
\hline Site 5\# & Bang hu & $115^{\circ} 59^{\prime} 48.9^{\prime \prime} \mathrm{E}$ & $29^{\circ} 10^{\prime} 00.5^{\prime \prime} \mathrm{N}$ & 17.52 \\
\hline Site 6\# & Donghu Chi & $116^{\circ} 00^{\prime} 57.1^{\prime \prime} \mathrm{E}$ & $29^{\circ} 09^{\prime} 45.6^{\prime \prime} \mathrm{N}$ & 11.51 \\
\hline Site 7\# & Dasaidi Lake & $116^{\circ} 02^{\prime} 15.0^{\prime \prime} \mathrm{E}$ & $29^{\circ} 10^{\prime} 49.5^{\prime \prime} \mathrm{N}$ & 16.10 \\
\hline Site 8\# & Xiushui (upstream) & $115^{\circ} 55^{\prime} 47.6^{\prime \prime} \mathrm{E}$ & $29^{\circ} 08^{\prime} 46.5^{\prime \prime} \mathrm{N}$ & 12.58 \\
\hline Site 9\# & Xiushui (downstream) & $116^{\circ} 00^{\prime} 24.2^{\prime \prime} \mathrm{E}$ & $29^{\circ} 11^{\prime} 00.4^{\prime \prime} \mathrm{N}$ & 12.51 \\
\hline Site 10\# & Gan River (upstream) & $116^{\circ} 00^{\prime} 27.4^{\prime \prime} \mathrm{E}$ & $29^{\circ} 07^{\prime} 40.6^{\prime \prime} \mathrm{N}$ & 14.39 \\
\hline Site 11\# & Gan River (downstream) & $116^{\circ} 01^{\prime} 08.6^{\prime \prime} \mathrm{E}$ & $29^{\circ} 10^{\prime} 45.7^{\prime \prime} \mathrm{N}$ & 10.01 \\
\hline Site 12\# & Confluence of two rivers & $116^{\circ} 01^{\prime} 09.5^{\prime \prime} \mathrm{E}$ & $29^{\circ} 11^{\prime} 34.0^{\prime \prime} \mathrm{N}$ & 12.46 \\
\hline
\end{tabular}


Table S2. Temperature and humidity conditions of Wucheng.

\begin{tabular}{|c|c|c|}
\hline Month & High/Low $\left({ }^{\circ} \mathrm{C}\right)$ & Humidity \\
\hline July $15^{\text {th }}, 2017$ & $36 / 28$ & 50 \\
\hline August $15^{\text {th }}, 2017$ & $30 / 25$ & 82 \\
\hline September $15^{\text {th }}, 2017$ & $29 / 20$ & 62 \\
\hline October $15^{\text {th }}, 2017$ & $17 / 15$ & 70 \\
\hline November $15^{\text {th }}, 2017$ & $20 / 13$ & 55 \\
\hline December $15^{\text {th }}, 2017$ & $7 / 3$ & 78 \\
\hline January $15^{\text {th }}, 2018$ & $14 / 6$ & 60 \\
\hline February $15^{\text {th }}, 2018$ & $13 / 6$ & 89 \\
\hline March $15^{\text {th }}, 2018$ & $22 / 8$ & 84 \\
\hline April $15^{\text {th }}, 2018$ & $20 / 10$ & 60 \\
\hline May $15^{\text {th }}, 2018$ & $35 / 27$ & 57 \\
\hline June $15^{\text {th }}, 2018$ & $32 / 21$ & 78 \\
\hline
\end{tabular}

Data sources: China Meteorological Administration and live recording

\section{Sample Preparation and Analysis}

\section{Water Sample Preparation}

The collected water sample was filtered with filter paper. First, $100 \mathrm{ml}$ filtered water sample was taken in a vacuum rotary evaporator and evaporated to just dry at $60^{\circ} \mathrm{C}$; second, $25 \mathrm{ml}$ methanol was added to the evaporation flask to dissolve the concentrate, and evaporated to just dry in a concentrated evaporator at $60^{\circ} \mathrm{C}$ again; third, the second concentrate was dissolved with $4 \mathrm{ml}$ methanol, and the solute was filtered using $0.45 \mu \mathrm{m}$ membrane, and the resulting solution was used for the analysis of niclosamide residues and its degradation intermediate products.

\section{Sample Analysis}

HPLC and HPLC/MS/MS were used to analyze the residual amount of niclosamide and its degradation intermediates in the collected water samples.

Niclosamide and its degradation intermediate products in water samples were qualitatively and quantitatively analyzed by HPLC (W2996/2695, Waters, USA). Samples were separated on a reversed-phase column (Kromasil $\mathrm{C} 18,250 \mathrm{~mm} \times 4.6 \mathrm{~mm}$ i.d.) with a guard column $(5 \mu \mathrm{m}, 10 \mathrm{~mm} \times 4.6 \mathrm{~mm}$ i.d.). Mobile phase consisted of $0.2 \%$ formic acid methanol solution (A) and distilled water (B) by using a gradient program of 50:50 (A:B, v/v) in 0 4 min, 60: 40 in $4 \sim 10 \mathrm{~min}$, 100: 0 in 10 13 $\mathrm{min}$, and 50:50 in 14 16 min. The flow rate was $1 \mathrm{~mL} / \mathrm{min}$ and column temperature was $20^{\circ} \mathrm{C}$. A photo-diode array (PDA) detector was set at $330 \mathrm{~nm}$ for acquiring chromatograms, however, the PDA detector was set at $285 \mathrm{~nm}$ for acquiring 5-chlorosalicylic acid chromatograms under the same chromatographic condition.

At the same time, the intermediates products of niclosamide degradation were identified by HPLC/MS/MS (Agilent 6538 Q-TOF System) equipped with an ESI source. As for the HPLC condition in HPLC/MS/MS testing, MeOH: $0.1 \%$ methanoic acid $=70: 30(\mathrm{v} / \mathrm{v})$ was used as mobile phase and flow rate was set to $0.2 \mathrm{~mL} \cdot \mathrm{min}^{-1}$ without a separation column. Full scale MS spectra both in negative ion mode and positive ion mode in the mass range between 50 and $500 \mathrm{~m} / \mathrm{z}$ was recorded.

\section{Risk Assessment}

The potential aquatic ecological risks of NCL and its degradation intermediates were assessed by using the risk quotients (RQ). According to the European technical guidance document on risk assessment (TGD) [17] the RQ value can be calculated by the following formula:

$$
\mathrm{RQ}=\frac{\mathrm{MEC}}{\mathrm{PNEC}}=\frac{\mathrm{MEC}}{\text { LOEC or LEC C50/AF }}
$$

...where MEC and PNEC are the measured environment concentration and predicted no effect concentration for niclosamide, respectively.

PNEC was obtained from short-term/acute toxicity data $\mathrm{L}(\mathrm{E}) \mathrm{C}_{50}$ divided by an assessment factor (AF) of 1000, or from long-term/chronic LOEC divided by 100 .

The RQ value of the intermediate products was calculated in the same way.

Aquatic toxicity data of niclosamide were from the USEPA Pesticides and Toxic Substances (7508C), EPA 738-R-99-007. 2-chloro-4-nitroaniline, from the experimental results of Jin [18], Li [19] and EC, aquatic toxicity data of 5-Chloro-2-hydroxybenzoic acid were from the experimental results of Trabalka, et al [20].

$$
\begin{aligned}
\text { MRQ } & =\sum_{i=1}^{n} \frac{\text { MECi }}{\text { PNECi }} \\
& =\sum_{i=i}^{n} \frac{\text { MECi }}{\text { min (PNECalgne, PNECinvertebrate, PNECfish) }}
\end{aligned}
$$

Mixed organic pollutants in water may increase the overall risk through synergistic effects [21]. Concentration addition model [22] was used to assess the mixture risk of niclosamide residues and its degradation intermediate present in natural waters, where MRQ--the mixtures risk quotient was calculated by adding together the highest RQ for the individual chemical material [21, 23].

Environmental risk was divided into three levels based on the calculated RQ value: $R Q<0.1$ is "low risk", $0.1 \leq R Q \leq 1$ mean "moderate risk", and $R Q>1$ represents "high risk" [24-26]. 


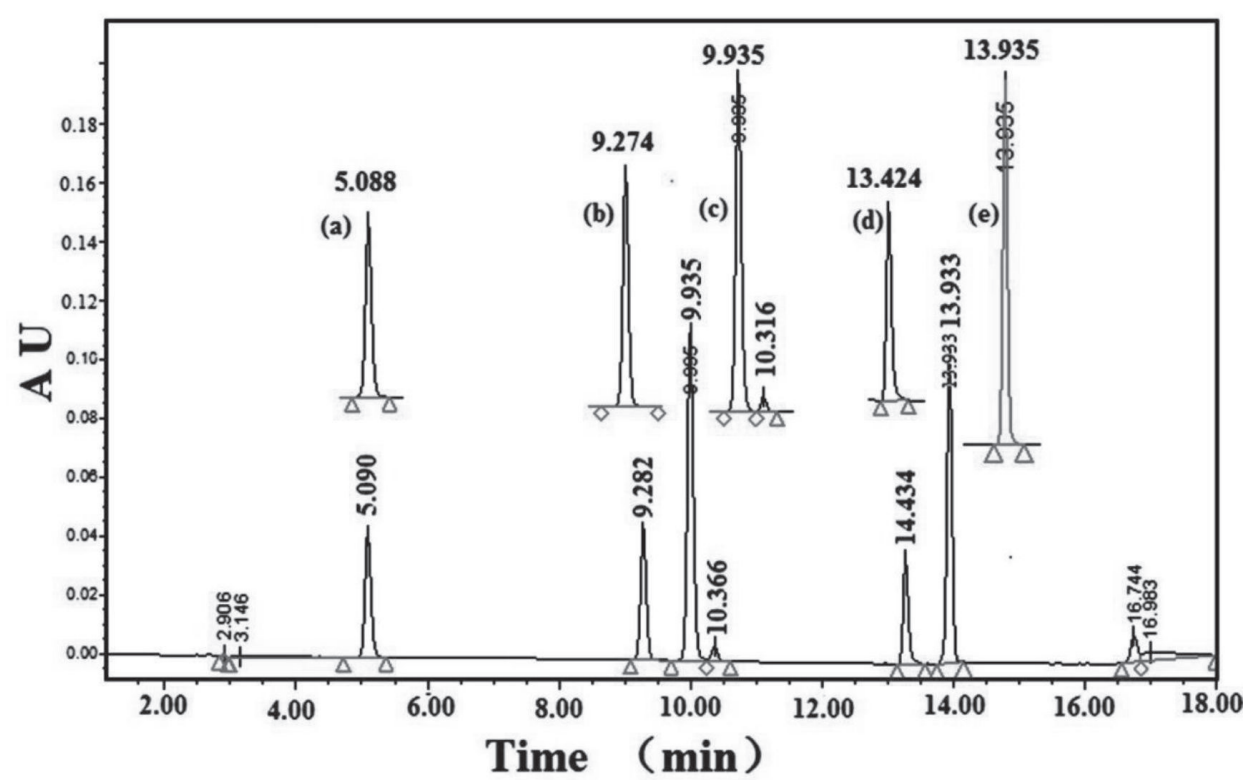

Fig. 2. HPLC spectrogram of niclosamide and possible intermediate standard samples: a) 2,5-dihydroxy benzoic acid $\left(4 \mathrm{mg} \cdot \mathrm{L}^{-1}\right)$, b) 2-chloro-4-nitroaniline $\left(4 \mathrm{mg} \cdot \mathrm{L}^{-1}\right)$, c) 2-chloro-4-nitrophenol $\left(4 \mathrm{mg} \cdot \mathrm{L}^{-1}\right)$, d) 5-chlorosalicylic acid $\left(4 \mathrm{mg} \cdot \mathrm{L}^{-1}\right)$, detection channel $285 \mathrm{~nm}$, e) niclosamid $\left(4 \mathrm{mg} \cdot \mathrm{L}^{-1}\right)$.

\section{Results and Discussion}

Niclosamide and its Intermediates in Water

\section{Niclosamide and Its Intermediates Standard Samples HPLC Analysis}

The intermediates produced by niclosamide degradation in natural water were mainly 2,5-dihydroxybenzoic acid, 2-chloro-4-nitroaniline, 2-chloro-4-nitrophenol and 5-chlorosalicylic acid [27]. Fig. 2 showed the HPLC chromatogram of niclosamide and possible intermediate standard samples. The retention time of 2,5-dihydroxy benzoic acid, 2-chloro4-nitroaniline, 2-chloro-4-nitrophenol, 5-chlorosalicylic acid, and niclosamide was 5.088, 9.274, 9.935, 13.424, and $13.935 \mathrm{~min}$, respectively. The results showed that the selected HPLC analytical conditions may be used for qualitative and quantitative analysis of niclosamide residues and its degradation main intermediates.

\section{Niclosamide and Its Intermediates in Water}

Water sample concentrates were qualitatively analyzed by HPLC. Fig. 3 was the HPLC chromatogram of water sample concentrates. It can be seen from Fig. 3a) that 2,5-dihydroxy benzoic acid (5.122 $\mathrm{min})$, 5-chlorosalicylic acid (13.436 $\mathrm{min})$ and niclosamide $(13.935 \mathrm{~min})$ components were detected in some river water samples, and 2,5-dihydroxybenzoic

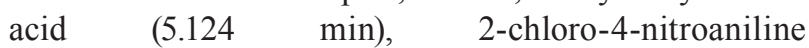
(9.241 min), 5-chlorosalicylic acid (13.434 min) and niclosamide $(13.942 \mathrm{~min})$ were detected in some lake waters(as shown in Fig. 3b). The retention times were $1.795,2.063,2.942,16.731$, and $17.117 \mathrm{~min}$, which were not qualitatively analyzed.

Fig. 4 was the HPLC/MS/MS of the water sample concentrates. The total ion current (TIC) (See Fig. S1) indicated that there were a number of substances in the water sample. The analysis results of TIC by MS/MS were shown in Fig. 4. Those results showed that there were several molecular ion peaks such as 152.8988 , $170.8874,172.0012,172.9946,325.1840$, etc. detected at $3.812,7.325,2.365,2.365$, and $8.164 \mathrm{~min}$ in TIC, respectively.

The analysis results of HPLC/MS/MS indicated that niclosamide $(\mathrm{m} / \mathrm{z}=325.1840)$ and its possible natural degradation intermediates (such as: 2,5-dihydroxy benzoic acid $(\mathrm{m} / \mathrm{z}=152.8988)$, 5-chlorosalicylic acid $(\mathrm{m} / \mathrm{z}=170.8831), \quad$ 2-chloro-4-nitroaniline $(\mathrm{m} / \mathrm{z}=172.0012), \quad 2$-chloro-4 -nitrophenol $(\mathrm{m} / \mathrm{z}=172.9946)$ occured in some Wucheng waters of Poyang Lake due to the use of niclosamide.

HPLC and HPLC/MS/MS analysis results showed that after using NCL, there were NCL residues and natural degradation intermediates such as 2,5-dihydroxy benzoic acid, 5-chlorosalicylic acid, 2-chloro-4nitroaniline, etc. in a certain period of time in the surrounding water environment.

\section{Niclosamide and Its Intermediates Concentration in Water}

The concentrations of niclosamide and its intermediates in the water samples were determined by external standard method using HPLC, the test results were shown in Table 1. The results in Table 1 indicated that there were different levels of niclosamide residues 

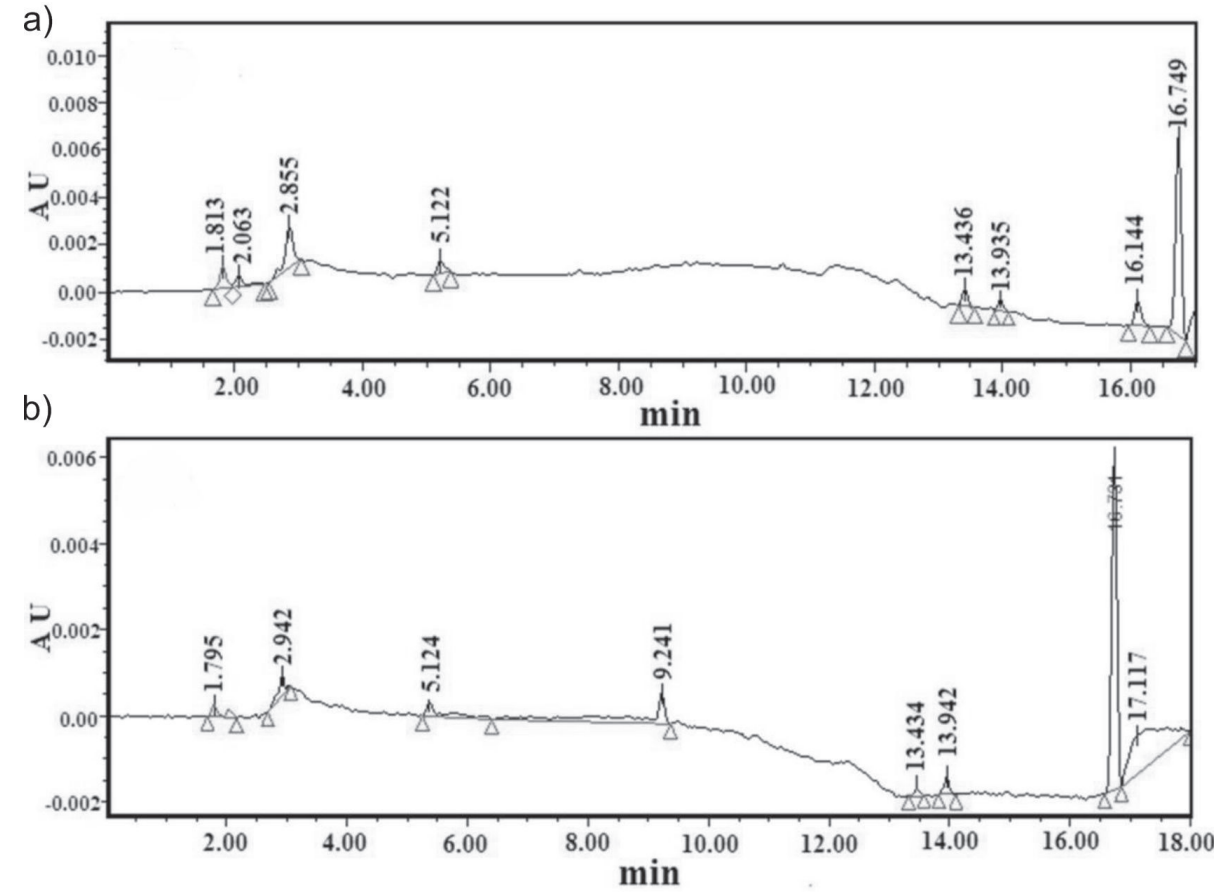

Fig. 3 HPLC spectrogram of water sample concentrates [concentration factor 4.0, a) River water, b) Lake water].
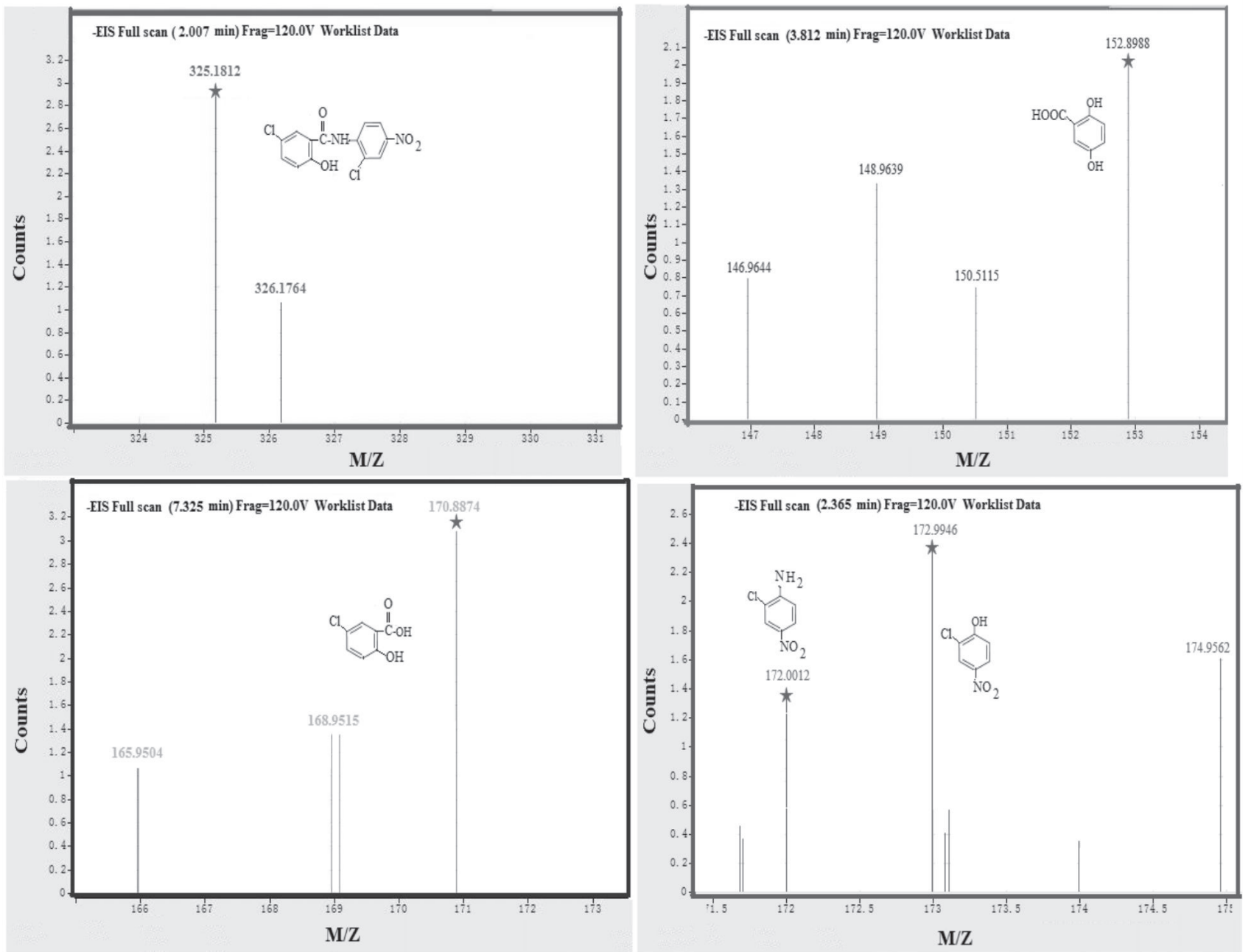

Fig. 4. HPLC-MS/MS analysis sketch of niclosamide and its degradation intermediate products in water sample concentrates. 


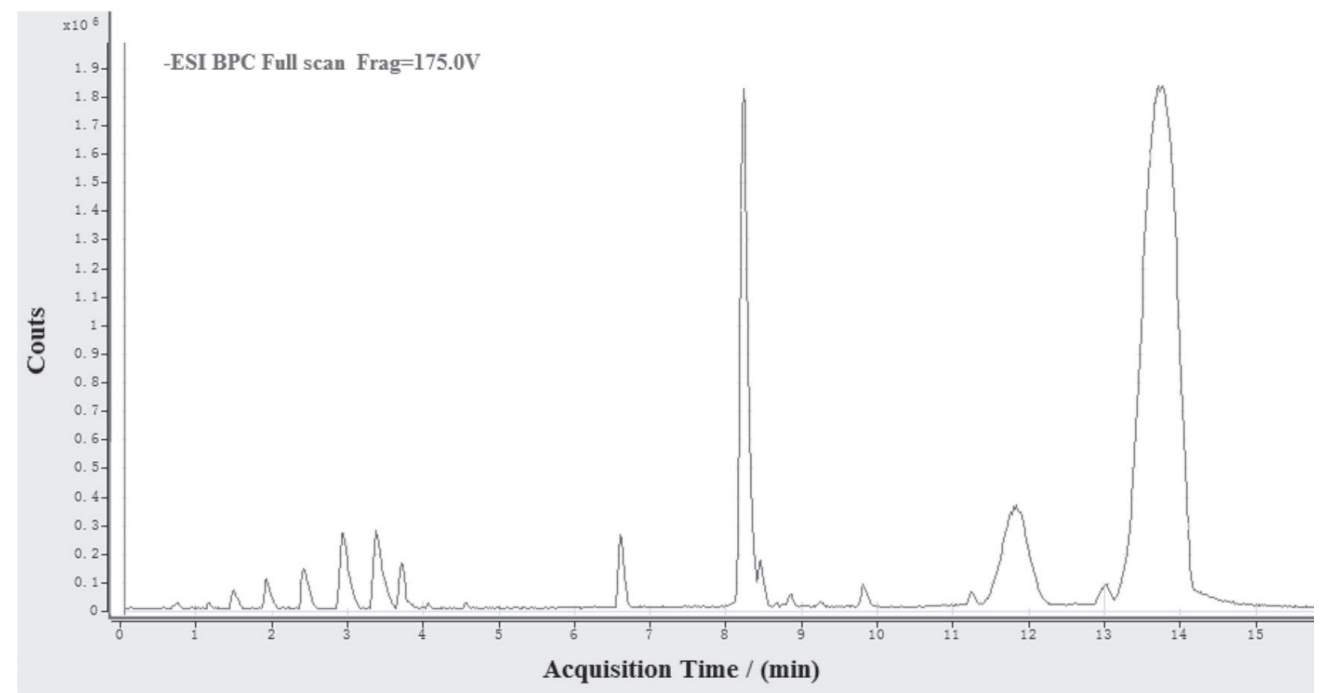

Fig. S1. TIC of water sample concentrate.

in the sampling water of Wucheng, the concentration range was $0.000 \sim 0.028 \mu \mathrm{g} / \mathrm{L}$ in Wucheng waters of Poyang Lake Basin.

It can be seen from Table 1 that the residual concentration of NCL in water has time seasonality and geographical location. Due to the dilution effect of the upstream river water, the residual concentration of NCL in the river water is less than that in the lake at the same time. Owing to the application of NCL twice a year, and the amount of rainfall, water temperature, sunlight, water body (organic matter, microorganisms, etc.) are different, the types and concentrations of NCL residues and intermediates are different in the same water body. Every year from March to May is the spawning period of snails. The schistosomiasis control center of Poyang Lake Basin use niclosamide to carry out two phases of snail-killing activities from April to May and from October to November.

Table1. Concentration of niclosamide and its degradation intermediate in water samples from Wucheng $\left(\mu \mathrm{g} \cdot \mathrm{L}^{-1}\right)$.

\begin{tabular}{|c|c|c|c|c|c|c|c|c|c|c|c|c|c|}
\hline \multicolumn{2}{|c|}{$7 \begin{array}{r}\text { Time } \\
\text { Site }\end{array}$} & $1 \#$ & $2 \#$ & $3 \#$ & $4 \#$ & $5 \#$ & $6 \#$ & $7 \#$ & $8 \#$ & 9\# & $10 \#$ & $11 \#$ & $12 \#$ \\
\hline \multirow{4}{*}{ July, 2017} & NCL & 0.005 & 0.006 & 0.013 & 0.010 & 0.013 & 0.011 & 0.009 & ND & ND & ND & ND & ND \\
\hline & DHBA & ND & ND & ND & $\mathrm{BML}^{*}$ & ND & ND & ND & ND & ND & ND & ND & ND \\
\hline & $2 \mathrm{C} 4 \mathrm{NA}$ & ND & ND & 0.008 & 0.006 & ND & ND & ND & ND & ND & ND & ND & ND \\
\hline & 5-CSA & ND & ND & 0.010 & 0.008 & 0.012 & 0.009 & 0.008 & 0.008 & ND & ND & ND & ND \\
\hline \multirow{4}{*}{ Aug, 2017} & NCL & ND & 0.003 & 0.005 & 0.008 & 0.012 & 0.010 & 0.004 & ND & 0.003 & ND & ND & ND \\
\hline & DHBA & ND & ND & ND & $\mathrm{BML}^{*}$ & ND & ND & ND & ND & ND & ND & ND & ND \\
\hline & $2 \mathrm{C} 4 \mathrm{NA}$ & ND & ND & 0.004 & ND & 0.007 & 0.006 & ND & ND & ND & ND & $\mathrm{ND}$ & ND \\
\hline & 5-CSA & ND & ND & ND & 0.010 & 0.009 & ND & 0.008 & ND & 0.008 & ND & ND & ND \\
\hline \multirow{4}{*}{ Sept, 2017} & NCL & ND & 0.005 & 0.007 & 0.009 & 0.009 & 0.007 & 0.008 & 0.005 & ND & 0.003 & ND & ND \\
\hline & DHBA & ND & ND & ND & $\mathrm{ND}$ & ND & $\mathrm{BML}^{*}$ & ND & ND & ND & $\mathrm{ND}$ & ND & ND \\
\hline & $2 \mathrm{C} 4 \mathrm{NA}$ & $\mathrm{ND}$ & ND & ND & $\mathrm{ND}$ & 0.007 & 0.006 & ND & ND & ND & $\mathrm{ND}$ & ND & ND \\
\hline & 5-CSA & 0.008 & ND & 0.009 & 0.010 & 0.009 & ND & 0.008 & ND & 0.008 & ND & ND & ND \\
\hline \multirow{4}{*}{ Oct, 2017} & NCL & ND & 0.003 & 0.009 & 0.013 & 0.011 & 0.020 & 0.005 & 0.006 & 0.008 & ND & 0.005 & 0.003 \\
\hline & DHBA & ND & ND & $\mathrm{BML}^{*}$ & $\mathrm{BML}^{*}$ & ND & BML $^{*}$ & $\mathrm{BML}^{*}$ & ND & ND & ND & ND & ND \\
\hline & $2 \mathrm{C} 4 \mathrm{NA}$ & ND & 0.008 & 0.008 & ND & 0.009 & 0.009 & 0.006 & ND & 0.006 & ND & ND & ND \\
\hline & 5-CSA & ND & $\mathrm{ND}$ & 0.010 & 0.013 & 0.008 & 0.015 & ND & 0.008 & 0.012 & ND & ND & 0.008 \\
\hline \multirow{4}{*}{ Nov, 2017} & NCL & 0.008 & 0.013 & 0.024 & 0.022 & 0.025 & 0.024 & 0.028 & 0.008 & 0.011 & 0.006 & 0.008 & $\mathrm{ND}$ \\
\hline & DHBA & ND & BML $^{*}$ & $\mathrm{BML}^{*}$ & $\mathrm{BML}^{*}$ & $\mathrm{BML}^{*}$ & $\mathrm{BML}^{*}$ & BML $^{*}$ & ND & ND & ND & ND & ND \\
\hline & $2 \mathrm{C} 4 \mathrm{NA}$ & 0.006 & 0.008 & 0.009 & 0.010 & 0.007 & ND & 0.013 & ND & 0.006 & ND & $\mathrm{ND}$ & ND \\
\hline & 5-CSA & ND & ND & 0.012 & 0.009 & 0.013 & 0.011 & 0.015 & ND & 0.009 & ND & 0.008 & ND \\
\hline
\end{tabular}


Table1. Continued.

\begin{tabular}{|c|c|c|c|c|c|c|c|c|c|c|c|c|c|}
\hline \multirow{4}{*}{ Dec, 2017} & NCL & 0.006 & 0.008 & 0.018 & 0.018 & 0.015 & 0.018 & 0.015 & ND & ND & 0.005 & ND & ND \\
\hline & DHBA & ND & ND & $\mathrm{BML}^{*}$ & $\mathrm{BML}^{*}$ & ND & $\mathrm{BML}^{*}$ & ND & ND & ND & ND & ND & ND \\
\hline & $2 \mathrm{C} 4 \mathrm{NA}$ & ND & 0.006 & 0.006 & ND & 0.008 & 0.007 & 0.009 & ND & ND & ND & ND & ND \\
\hline & 5-CSA & ND & $\mathrm{ND}$ & 0.012 & 0.011 & 0.008 & 0.010 & 0.016 & ND & 0.009 & ND & ND & ND \\
\hline \multirow{4}{*}{ Jan, 2018} & NCL & ND & ND & 0.005 & 0.011 & 0.011 & 0.010 & 0.010 & ND & $\mathrm{ND}$ & 0.006 & ND & ND \\
\hline & DHBA & ND & ND & ND & $\mathrm{BML}^{*}$ & ND & ND & ND & ND & $\mathrm{ND}$ & ND & ND & ND \\
\hline & $2 \mathrm{C} 4 \mathrm{NA}$ & ND & ND & ND & ND & 0.008 & 0.006 & ND & ND & 0.006 & ND & ND & ND \\
\hline & 5-CSA & ND & ND & 0.010 & 0.010 & 0.008 & ND & ND & ND & ND & ND & ND & ND \\
\hline \multirow{4}{*}{ Feb, 2018} & $\mathrm{NCL}$ & ND & ND & 0.007 & 0.009 & 0.008 & 0.009 & 0.010 & 0.004 & ND & ND & ND & ND \\
\hline & DHBA & ND & ND & $\mathrm{ND}$ & ND & ND & ND & $\mathrm{ND}$ & ND & ND & ND & ND & ND \\
\hline & $2 \mathrm{C} 4 \mathrm{NA}$ & ND & ND & ND & ND & 0.006 & ND & ND & ND & ND & ND & ND & ND \\
\hline & 5-CSA & ND & 0.008 & $\mathrm{ND}$ & ND & ND & ND & ND & ND & ND & 0.008 & ND & ND \\
\hline \multirow{4}{*}{ Mar, 2018} & NCL & 0.003 & ND & 0.008 & 0.011 & 0.0013 & 0.006 & 0.008 & ND & 0.003 & ND & ND & ND \\
\hline & DHBA & ND & ND & ND & ND & BML $^{*}$ & ND & BML $^{*}$ & ND & ND & ND & ND & ND \\
\hline & $2 \mathrm{C} 4 \mathrm{NA}$ & ND & ND & ND & 0.006 & 0.008 & 0.006 & ND & 0.006 & ND & ND & ND & ND \\
\hline & 5-CSA & ND & ND & ND & ND & 0.0010 & ND & 0.009 & ND & 0.008 & ND & ND & ND \\
\hline \multirow{4}{*}{ Apr, 2018} & NCL & ND & 0.004 & 0.010 & 0.013 & 0.023 & 0.018 & 0.007 & 0.003 & ND & ND & 0.004 & ND \\
\hline & DHBA & ND & ND & ND & $\mathrm{BML}^{*}$ & $\mathrm{BML}^{*}$ & $\mathrm{BML}^{*}$ & ND & ND & 0.006 & ND & 0.006 & ND \\
\hline & 2C4NA & ND & ND & 0.006 & 0.009 & 0.010 & 0.008 & ND & 0.006 & ND & ND & ND & ND \\
\hline & 5-CSA & ND & ND & 0.008 & 0.011 & 0.016 & 0.010 & ND & 0.008 & 0.009 & ND & 0.008 & ND \\
\hline \multirow{4}{*}{ May, 2018} & NCL & 0.009 & 0.013 & 0.026 & 0.023 & 0.015 & 0.016 & 0.018 & 0.005 & 0.003 & 0.003 & 0.003 & ND \\
\hline & DHBA & ND & $\mathrm{BML}^{*}$ & $\mathrm{BML}^{*}$ & $\mathrm{BML}^{*}$ & $\mathrm{BML}^{*}$ & $\mathrm{BML}^{*}$ & $\mathrm{BML}^{*}$ & ND & $\mathrm{BML}^{*}$ & ND & ND & ND \\
\hline & $2 \mathrm{C} 4 \mathrm{NA}$ & 0.006 & 0.006 & 0.013 & 0.015 & 0.008 & 0.007 & 0.009 & 0.006 & 0.008 & 0.006 & ND & ND \\
\hline & 5-CSA & 0.008 & 0.010 & 0.018 & 0.017 & 0.019 & 0.008 & 0.012 & 0.008 & 0.010 & ND & 0.008 & ND \\
\hline \multirow{4}{*}{ June, 2018} & NCL & 0.008 & 0.008 & 0.018 & 0.014 & 0.012 & 0.006 & 0.013 & ND & ND & 0.005 & ND & ND \\
\hline & DHBA & $\mathrm{BML}^{*}$ & ND & $\mathrm{BML}^{*}$ & $\mathrm{BML}^{*}$ & $\mathrm{BML}^{*}$ & ND & $\mathrm{BML}^{*}$ & $\mathrm{BML}^{*}$ & ND & ND & ND & ND \\
\hline & $2 \mathrm{C} 4 \mathrm{NA}$ & ND & $\mathrm{ND}$ & 0.006 & 0.006 & 0.007 & 0.006 & ND & ND & ND & ND & ND & ND \\
\hline & 5-CSA & ND & 0.008 & 0.011 & 0.009 & 0.008 & ND & ND & 0.008 & ND & ND & ND & ND \\
\hline
\end{tabular}

Note: BML: Below the monitoring line; ND: not detected;NCL: niclosamide; DHBA: 2,5-dihydroxy benzoic acid; 2C4NA:

2-chloro-4-nitroaniline; 5-CSA: 5-chlorosalicylic acid

The concentration of niclosamide in the water was greatly increased during the application. The concentration of small lakes near the residential area $(5 \#, 7 \#)$ is the highest, and the concentration of large lakes such as $1 \#$ and Site $2 \#$ is relatively low; Two months after the application of NCL, the concentration of niclosamide residue in the water was reduced to a relatively stable state.

In summer, high temperatures and long periods of sunshine favor photolysis and microbial degradation of niclosamide. At the same time, under the action of the upper aerobic microorganisms and the bottom layer anaerobic microorganisms in the water, the NCL adsorbed on the surface of the particles and sludge in the condition of aerobic-anaerobic degradation, and an intermediate product had a larger solubility than NCL is formed. Thereby, the number of intermediate products degraded by NCL in the water body increases and its concentration also increases. In winter, the sun is weak, the water temperature is low, the microbial activity is weak, and the NCL adsorbed on the sediment surface hardly reacts.

During summer, due to the large rainfall, strong sunlight and high water temperature, the residual concentration of niclosamide in the water is lower than that in winter.

At the same time, it can be seen from Table 1 that after using NCL to kill snails in the Wucheng area, the NCL in the water body generates intermediates such as 5-chlorosalicylic acid, 2-chloro-4-nitroaniline, 2,5-dihydroxybenzoicacid under the action of sunlight and microorganisms. 5-chlorosalicylic acid concentrations in water samples collected in $1 \# \sim 12 \#$ were in the range of $0 \sim 0.019 \mu \mathrm{g} / \mathrm{L}, 2$-chloro-4nitrobenzene concentration in the sample collection points were in the range of $0 \sim 0.014 \mu \mathrm{g} / \mathrm{L}$, and the concentration of 2,5-dihydroxybenzoicacid is less than the detection line of this test instrument. 
Table 2. Aquatic toxicity data of niclosamide and its degradation intermediate to the most sensitive aquatic species.

\begin{tabular}{|c|c|c|c|c|c|c|}
\hline Compound & Non-target organism & $\begin{array}{l}\text { Toxicity data } \\
(\mathrm{mg} / \mathrm{L})\end{array}$ & Toxicity & $\mathrm{AF}^{\mathrm{a}}$ & $\begin{array}{l}\mathrm{PNEC}^{\mathrm{b}} \\
(\mathrm{ng} / \mathrm{L})\end{array}$ & Reference \\
\hline \multirow{4}{*}{$\mathrm{NCL}$} & Aquatic plant (algae) & $\mathrm{EC}_{50}=0.04->1.45$ & Acute & 1000 & 40 & $\begin{array}{l}\text { EPA 738-R-99-007, } \\
\text { (1999) [8] }\end{array}$ \\
\hline & Invertebrates (freshwater) & $\mathrm{EC}_{50}=0.034->50$ & Acute & 1000 & $34 \sim 50000$ & $\begin{array}{c}\text { EPA 738-R-99-007, } \\
(1999)\end{array}$ \\
\hline & Invertebrates (freshwater) & $\mathrm{NOAE}^{\mathrm{C}}=0.034$ & chronic & 100 & 34 & $\begin{array}{c}\text { EPA 738-R-99-007, } \\
(1999)\end{array}$ \\
\hline & Fish (Fresh water) & $\mathrm{LC}_{50}=0.03-0.23$ & Acute & 1000 & $30 \sim 230$ & $\begin{array}{l}\text { EPA 738-R-99-007, } \\
(1999)\end{array}$ \\
\hline $5-\mathrm{CSA}$ & Invertebrates (water flea) & $\mathrm{LC}_{50}>100$ & Acute & 1000 & 100000 & $\begin{array}{c}\text { Trabalka,J.R, et al, } \\
\text { (1978) [20] }\end{array}$ \\
\hline \multirow{3}{*}{ 2C4NA } & Aquatic plant (algae) & $\mathrm{EC}_{50}^{\mathrm{d}}=1.81$ & acute & 1000 & 1810 & Jin, et al, (2014)[18] \\
\hline & $\begin{array}{c}\text { Invertebrates } \\
\text { (daphnia magna) }\end{array}$ & $\mathrm{NOAEC}^{\mathrm{e}}=3.2$ & acute & 100 & 320 & $\begin{array}{c}\text { ECB 121-87-9, (2000) } \\
{[29]}\end{array}$ \\
\hline & Fish (Fresh water) & $\mathrm{LC}_{50}{ }^{\mathrm{f}}=6.99$ & Acute & 1000 & 6990 & Li, et al,(2001) [19] \\
\hline
\end{tabular}

a. AF: assessment factor; b. b PNEC: predicted no effect concentration. C. NOEC: no observable effect concentration; d. EC Fo $_{50}$ : half maximal effective concentration; e. NOAEC- No Observed Adverse Effect Concentration; f. LC $_{50}-$ Median Lethal Concentration;

\section{Aquatic Ecological Risk}

After being used in the Wucheng waters of the Poyang Lake Basin, NCL directly enters the surrounding water, sediment and soil environment, under the influence of factors such as sunlight, plants and microorganisms, NCL migrates and transforms in the water-sediment-soil system, producing many degradation intermediates such as 2-chloro-4nitroaniline, 5-chlorosalicylic acid, 2,5-dihydroxy benzoic acid, etc. Due to the long-term use of NCL twice a year, the water in Wucheng waters contains NCL residues and intermediates such as 2-chloro4-nitroaniline, 5-chlorosalicylic acid, 2,5-dihydroxy benzoic acid, and their concentrations were not equal at different times and in different locations (See Table 1).

At the concentration used for snail control, NCL has no effect on important aquatic plants (such as rice, grass, mustard, etc.) [28] in the schistosomiasi control area, however, for aquatic plants (algae), Invertebrates and Fish, NCL is highly toxic due to the lower $\mathrm{L}(\mathrm{E}) \mathrm{C}_{50}$ (or LOEC) values, and their PNEC values are 40, 34, $30 \mathrm{ng} / \mathrm{L}$, respectively (See Table 2). At the same time, 2-chloro-4-nitroaniline was also highly toxic to algae, Invertebrates and Fish due to its lower $\mathrm{L}(\mathrm{E}) \mathrm{C} 50$ (or LOEC) values (See Table 2).

Due to the dilution effect of the upstream water from the river, the environmental risk of NCL residues in the river water in Wucheng is low risk, and the RQ value is less than 0.1 (See Table S3).

NCL residue has moderate environmental risk to algae, invertebrate, and fish in lake water environment in Wucheng waters, and its RQ value is between 0.2 and 0.8 , especially in April, May, October and November of the NCL application period, the RQ value in the lake water environment is between 0.5 and 0.8 , indicating that the lake water presents moderate ecological risk.

After being degraded by NCL, 2-chloro-4nitroaniline, 5-chlorosalicylic acid had no effect on algae, invertebrate, and fish in the river water environment of Wucheng, because their corresponding RQ values were less than 0.01. However, for lake water, these intermediates have a minor effect on the algae, invertebrate, and fish in the lake because their corresponding RQ values sometimes reach 0.05 .

The risk assessment of the detected NCL residue and its degradation intermediates mixture was conducted based on the classical mixture toxicity concept of concentration addition model. As shown in Fig. 5 and Table S3, the calculated MRQ values of NCL residue, 2-chloro-4-nitroaniline and 5-chlorosalicylic acid mixtures in the lake water sampling sites $(1 \# \sim 7 \#)$ for sensitive algae, invertebrates and fish is $0.000 \sim 0.707$, $0.000 \sim 0.864,0.000 \sim 0.935$ respectively. MRQ values at all of the lake water sampling sites (1\# 7\#) were in the range of 0.00 to 0.935 , which indicated that the detected NCL residue,2-chloro-4-nitroaniline and 5-chlorosalicylic acid mixtures might pose a moderate ecological risks.

Meanwhile, Table S3 allowed a clear identification of the relative importance of each individual substance. NCL residue and 2-chloro-4-nitroaniline contributed $94.0 \% \sim 99.0 \%$ and $0 \% \sim 5.8 \%$ to the MRQs for each site, respectively, while 5-chlorosalicylic acid only has a negligible contribution.

At the same time, MRQ values of NCL residue, 2-chloro-4-nitroaniline and 5-chlorosalicylic acid mixtures in the river water sampling sites $(8 \# \sim 12 \#)$ were in the range of $0.000 \sim 0.168$. which indicated that the use of NCL is low risk for regional river water. 


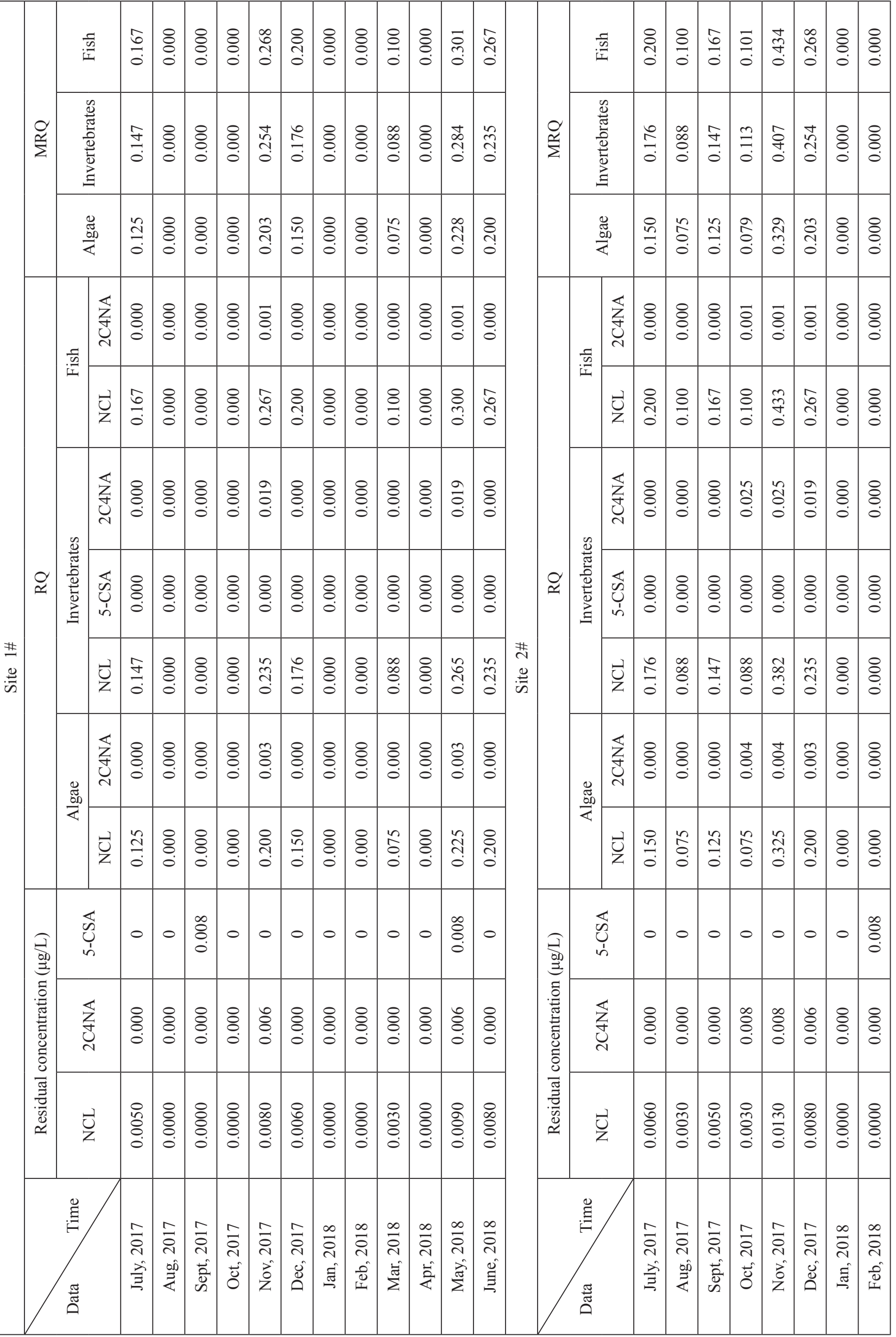




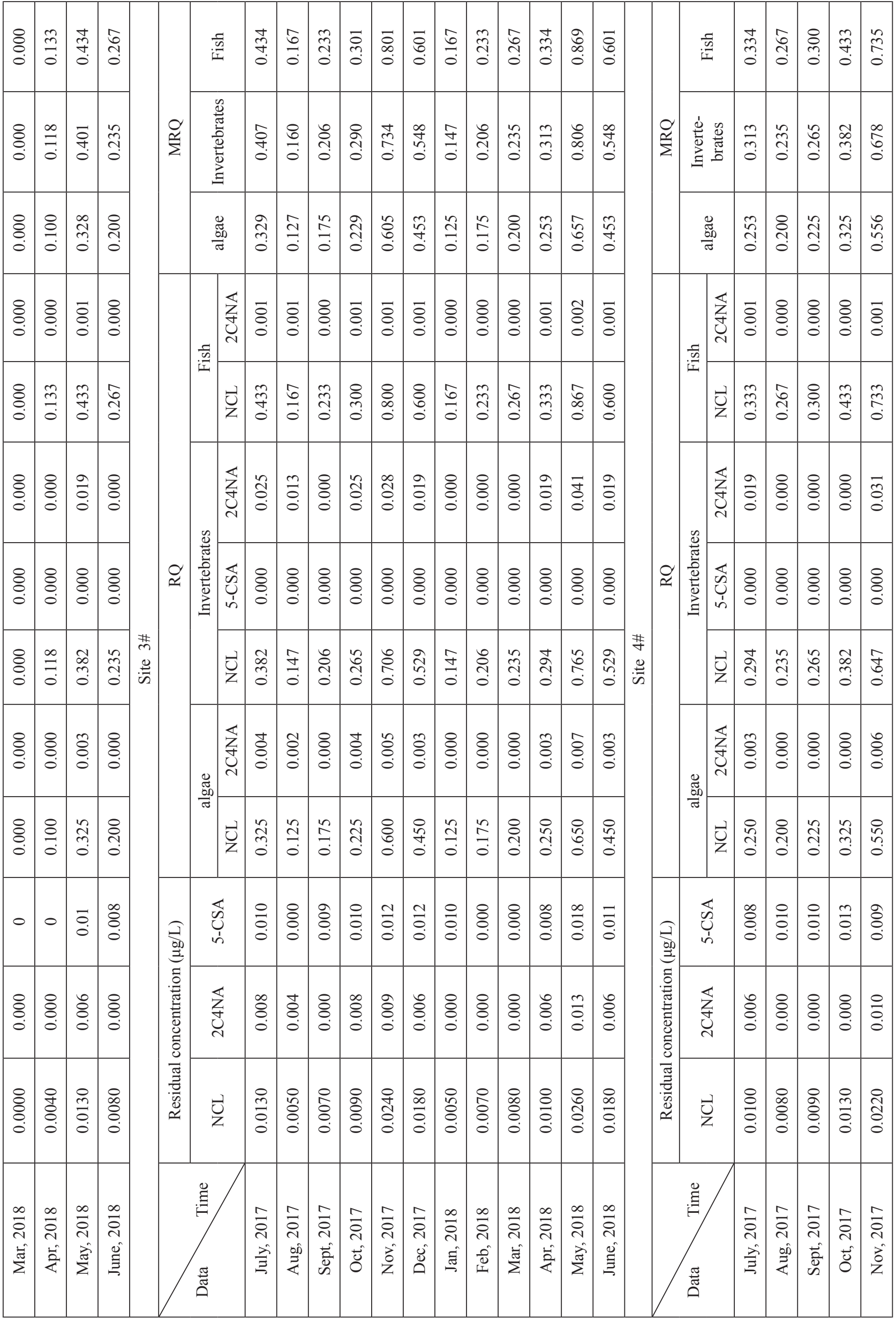




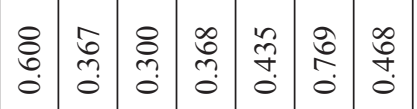

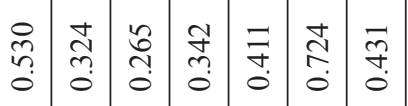

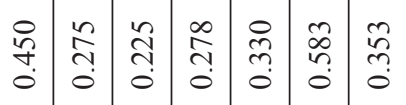

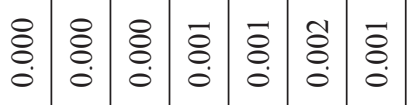

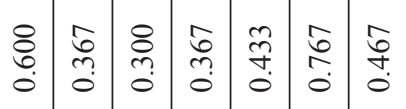

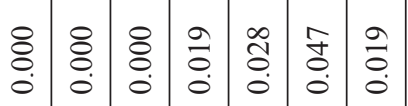

‡

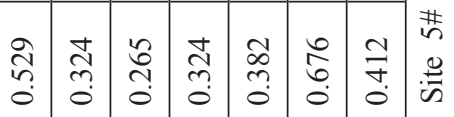

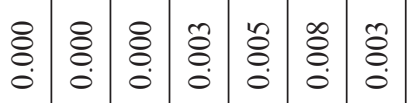

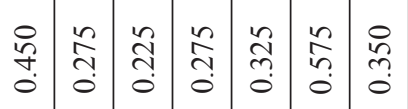

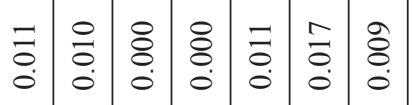

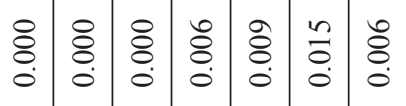

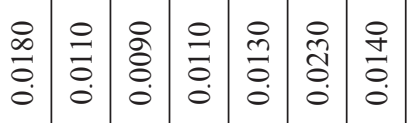

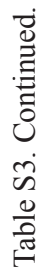

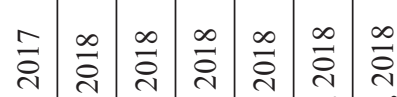

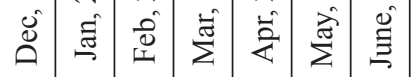

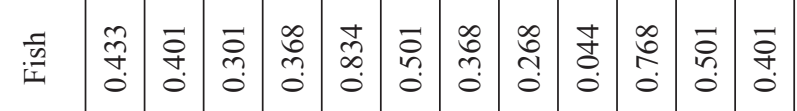

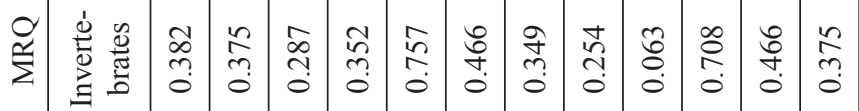

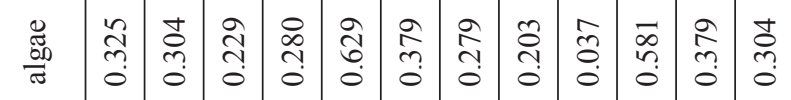

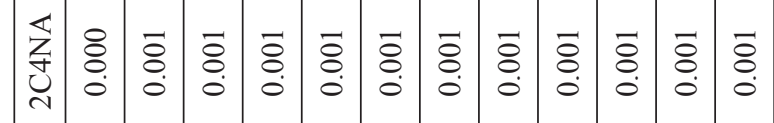

竞

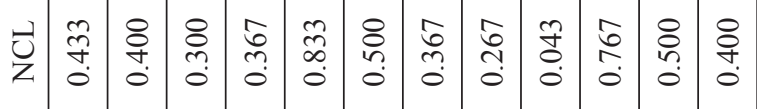

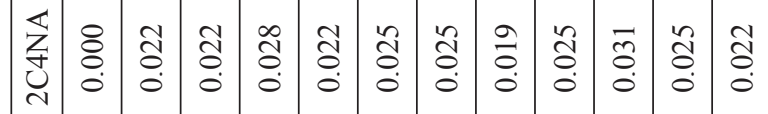

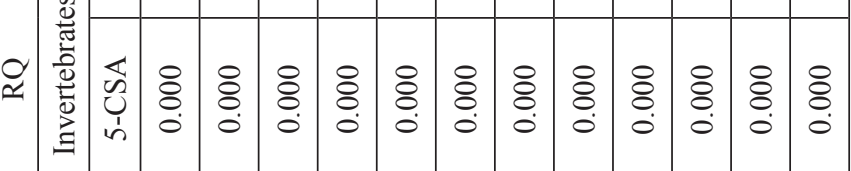

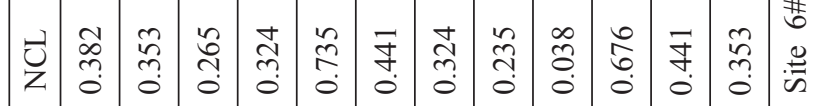

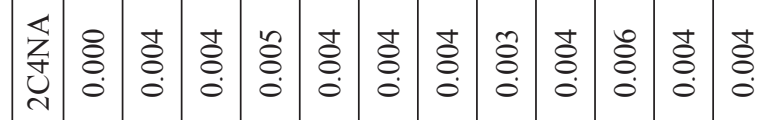

总

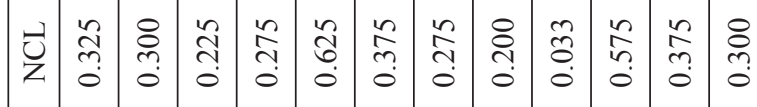

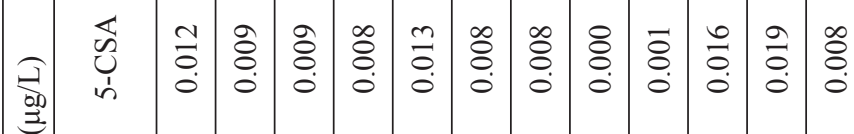

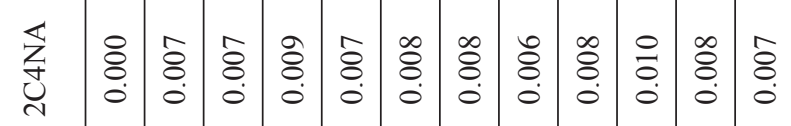

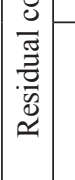

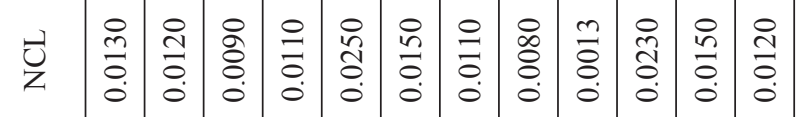

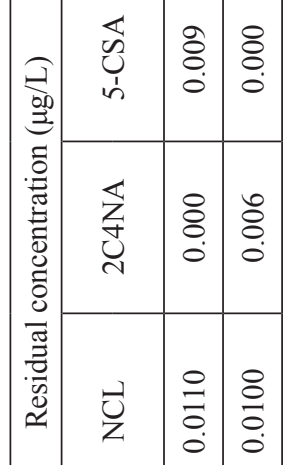

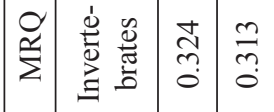

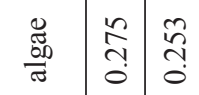

需

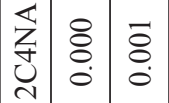

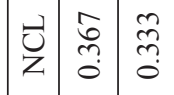

苾

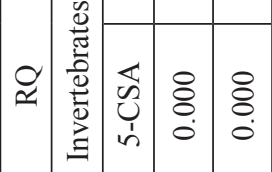

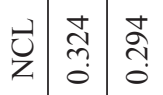

麦

总

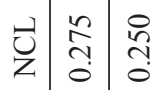

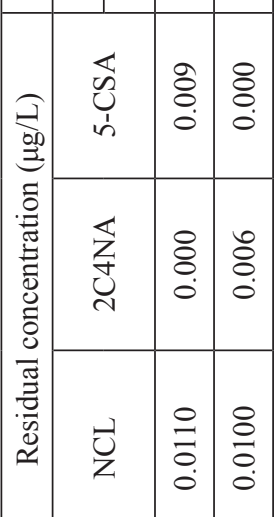




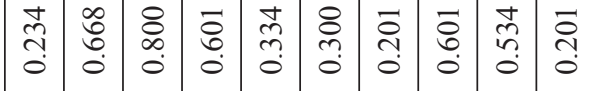

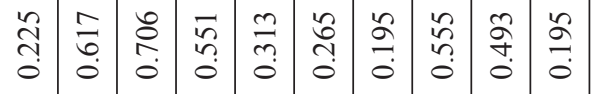

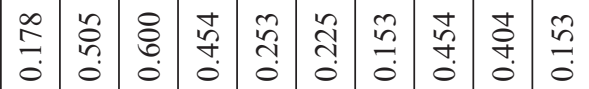

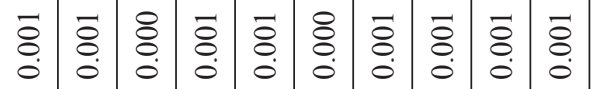

ஸి

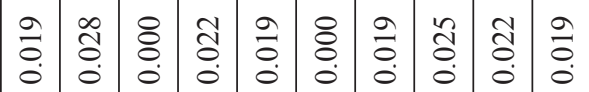

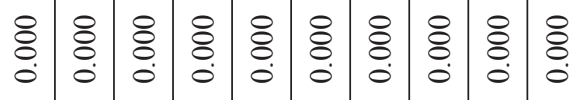

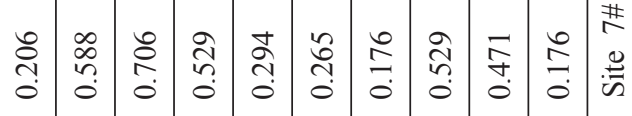

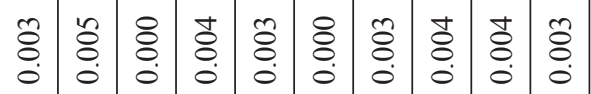

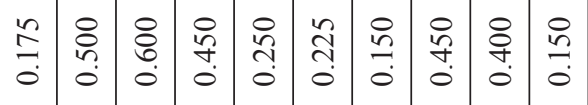

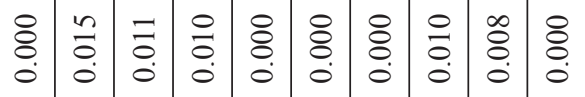

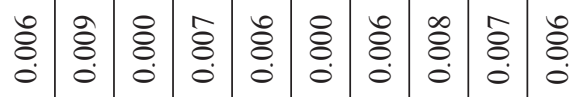

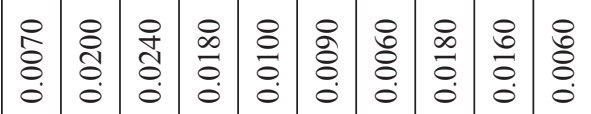

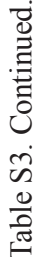

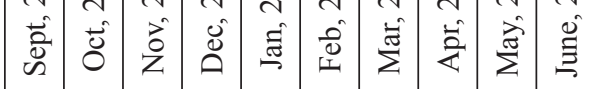

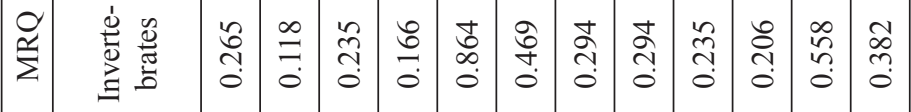

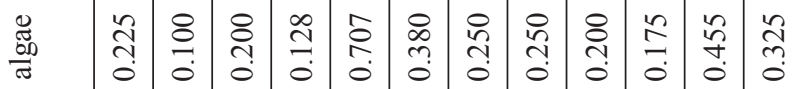
艺 雳

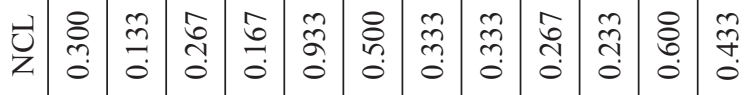

艺

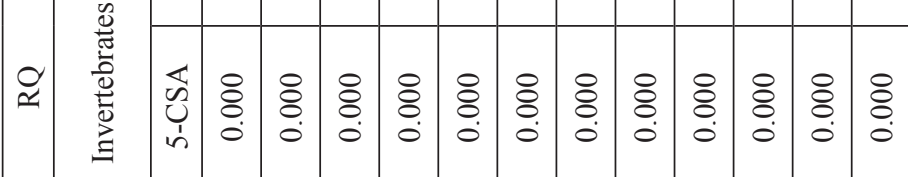

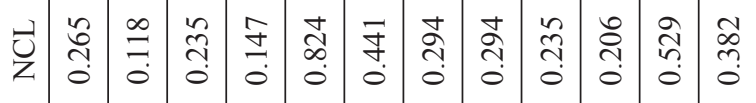

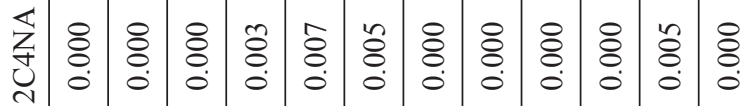
त्व

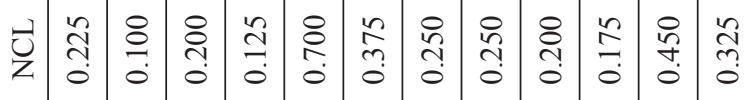

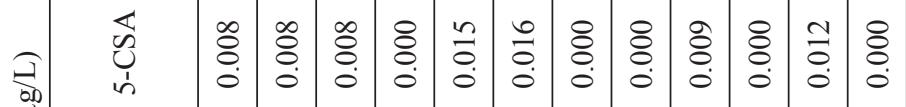

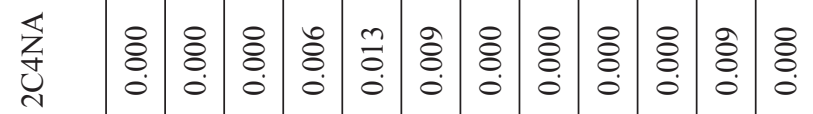

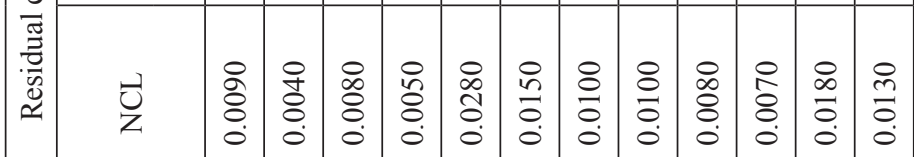
:

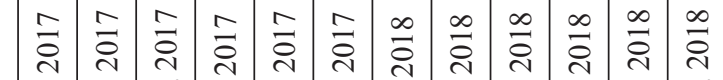

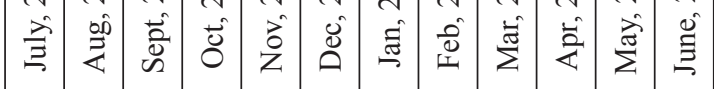




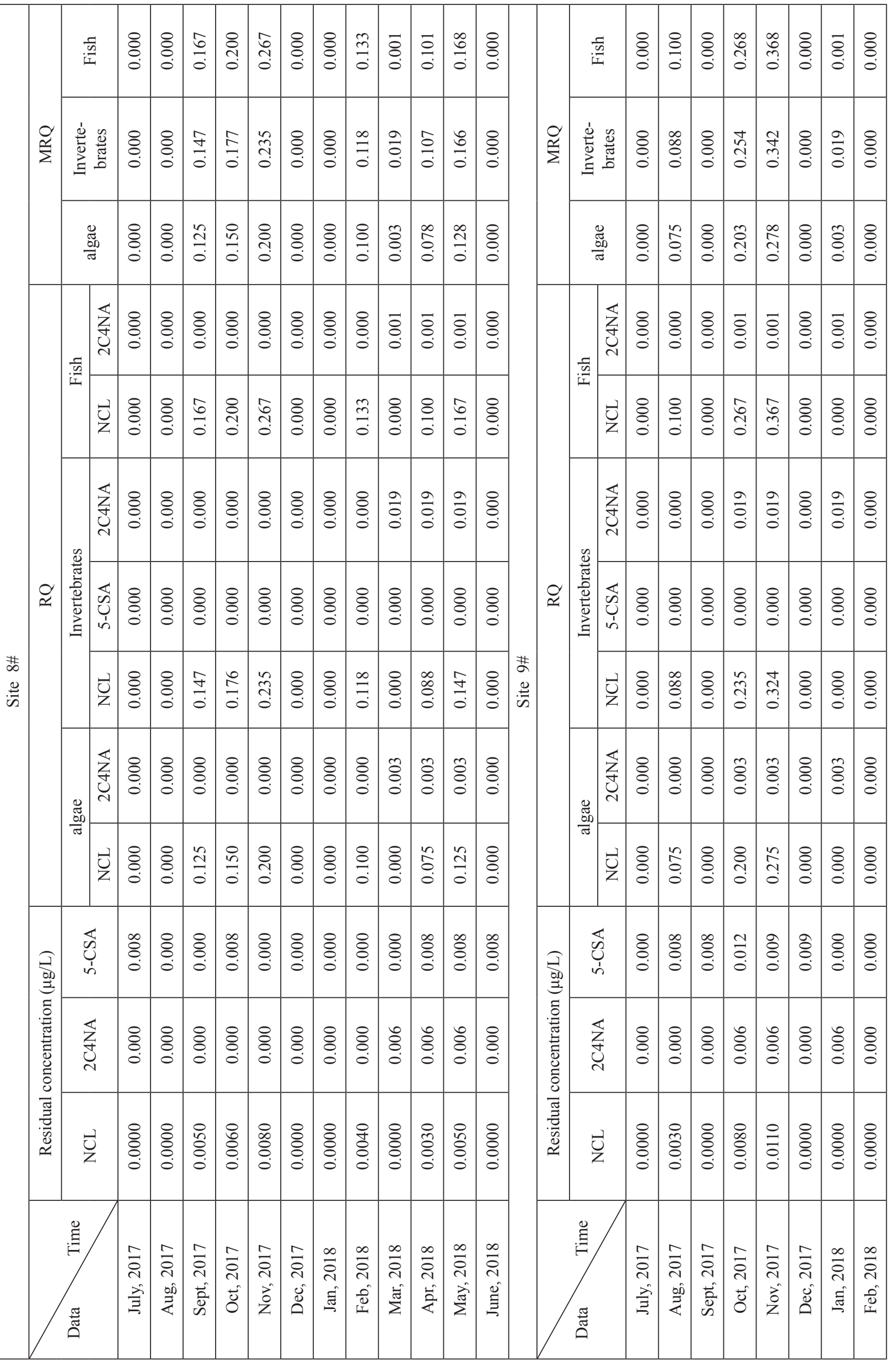




\begin{tabular}{|c|c|c|c|c|c|c|c|c|c|c|c|c|c|c|c|c|c|c|c|c|c|c|c|c|c|}
\hline$\frac{8}{0}$ & \&. & $\stackrel{\vec{\circ}}{\circ}$ & \&. & & & 厾 & $\stackrel{8}{8}$ & $\begin{array}{l}8 \\
8 \\
0\end{array}$ & $\begin{array}{l}8 \\
\stackrel{0}{0}\end{array}$ & $\begin{array}{l}8 \\
\vdots \\
0\end{array}$ & $\begin{array}{l}8 \\
\stackrel{1}{1} \\
0\end{array}$ & $\begin{array}{c}\overline{0} \\
\vdots \\
0\end{array}$ & $\begin{array}{l}8 \\
\stackrel{1}{1} \\
0\end{array}$ & $\begin{array}{l}0 \\
\vdots \\
0 \\
0\end{array}$ & $\begin{array}{l}0 \\
\vdots \\
0 \\
0\end{array}$ & $\begin{array}{l}8 \\
\vdots \\
\vdots \\
0\end{array}$ & $\begin{array}{c}\overline{0} \\
\vdots \\
0\end{array}$ & $\begin{array}{l}5 \\
0 \\
0\end{array}$ & & & 氞 & $\begin{array}{l}8 \\
\vdots \\
0\end{array}$ & \&̊. & \& & $\frac{5}{0}$ \\
\hline $\begin{array}{l}\infty \\
\infty \\
0 \\
0 \\
0\end{array}$ & $\begin{array}{l}8 \\
\vdots \\
0\end{array}$ & $\stackrel{m}{=}$ & : & & $\begin{array}{l}q \\
\Sigma \\
\Sigma\end{array}$ & 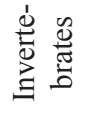 & \& & $\begin{array}{l}8 \\
\vdots \\
0\end{array}$ & $\begin{array}{l}\infty \\
\infty \\
0 \\
0\end{array}$ & $\begin{array}{l}8 \\
\vdots \\
0 \\
0\end{array}$ & 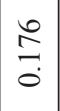 & $\begin{array}{l}\text { 守 } \\
0\end{array}$ & 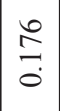 & \begin{tabular}{l}
8 \\
\hdashline \\
0 \\
0
\end{tabular} & $\begin{array}{l}8 \\
\vdots \\
0 \\
0\end{array}$ & $\begin{array}{l}8 \\
\vdots \\
0 \\
\end{array}$ & $\begin{array}{l}0 \\
\vdots \\
0\end{array}$ & 守 & & 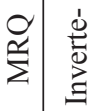 & 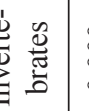 & $\stackrel{8}{\circ}$ & $\stackrel{8}{\circ}$ & $\stackrel{8}{\circ}$ & $\frac{0}{\dot{S}}$ \\
\hline $\begin{array}{l}\text { ñ } \\
\vdots \\
0 \\
0\end{array}$ & ¿. & $\begin{array}{l}\Omega \\
\hat{o} \\
\stackrel{0}{0}\end{array}$ & \begin{tabular}{l}
8 \\
\hdashline \\
$\circ$
\end{tabular} & & & $\begin{array}{l}\stackrel{\mathscr{J}}{\sigma} \\
\frac{\text { ond }}{\sigma}\end{array}$ & $\stackrel{8}{\circ}$ & \&. & $\begin{array}{l}n \\
\vdots \\
0 \\
0\end{array}$ & $\begin{array}{l}8 \\
\vdots \\
0 \\
0\end{array}$ & $\stackrel{8}{?}$ & $\stackrel{2}{\mathfrak{1}}$ & 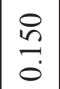 & $\begin{array}{l}8 \\
\vdots \\
0 \\
0\end{array}$ & \begin{tabular}{l}
8 \\
\hdashline \\
\hdashline
\end{tabular} & $\begin{array}{l}8 \\
\vdots \\
0\end{array}$ & \begin{tabular}{|l}
$\infty$ \\
0 \\
0 \\
0 \\
0
\end{tabular} & $\stackrel{2}{\dddot{2}}$ & & & 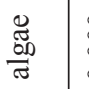 & $\stackrel{8}{\circ}$ & \&̊م. & \&̊م. & $\stackrel{2}{\frac{2}{0}}$ \\
\hline $\begin{array}{l}8 \\
\vdots \\
0\end{array}$ & $\begin{array}{l}8 \\
\vdots \\
\circ\end{array}$ & Бे & ¿े & & & 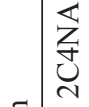 & 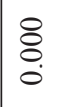 & $\begin{array}{l}8 \\
8 \\
0\end{array}$ & $\begin{array}{l}8 \\
\vdots \\
0\end{array}$ & $\begin{array}{l}0 \\
\vdots \\
0 \\
0\end{array}$ & $\begin{array}{l}8 \\
\vdots \\
0 \\
0\end{array}$ & $\begin{array}{l}8 \\
8 \\
0 \\
0\end{array}$ & $\begin{array}{l}8 \\
\vdots \\
0 \\
0\end{array}$ & $\begin{array}{l}8 \\
\vdots \\
0\end{array}$ & $\begin{array}{l}0 \\
\vdots \\
0\end{array}$ & $\begin{array}{l}8 \\
\vdots \\
0 \\
\end{array}$ & $\overrightarrow{8}$ & $\begin{array}{l}8 \\
8 \\
0\end{array}$ & & & $\mid$\begin{tabular}{c}
$\overleftrightarrow{z}$ \\
\multirow{Z}{Z}{}
\end{tabular} & $\stackrel{8}{8}$ & $\stackrel{8}{8}$ & $\stackrel{8}{8}$ & $\stackrel{8}{\circ}$ \\
\hline$\frac{8}{0}$ & ¿̊. & $\frac{8}{0}$ & \begin{tabular}{l}
8 \\
\hdashline
\end{tabular} & & & $\vec{Z}$ & \&. & \&̊. & $\frac{8}{0}$ & $\begin{array}{l}8 \\
\vdots \\
0\end{array}$ & 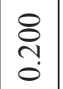 & $\begin{array}{c}\hat{0} \\
0 \\
0\end{array} \mid$ & 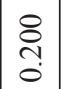 & $\begin{array}{l}8 \\
\stackrel{0}{0}\end{array}$ & $\begin{array}{l}8 \\
\stackrel{0}{0}\end{array}$ & $\stackrel{8}{\circ}$ & $\frac{8}{0}$ & $\frac{1}{0}$ & & & $\vec{Z}$ & $\stackrel{8}{\circ}$ & @̣̊. & \&̊م. & $\begin{array}{l}\hat{\sigma} \\
0 \\
0\end{array}$ \\
\hline $\begin{array}{l}8 \\
\vdots \\
0\end{array}$ & \&̊. & ڤิ & $\stackrel{8}{\circ}$ & & & $\begin{array}{l}\underset{Z}{Z} \\
\underset{N}{Z}\end{array}$ & 8 & \&̊ & $\begin{array}{l}8 \\
8 \\
0\end{array}$ & $\begin{array}{l}0 \\
0 \\
0 \\
0\end{array}$ & $\begin{array}{l}8 \\
8 \\
0\end{array}$ & $\begin{array}{l}8 \\
8 \\
0 \\
0\end{array}$ & $\begin{array}{l}0 \\
8 \\
0 \\
0\end{array}$ & $\begin{array}{l}8 \\
8 \\
0 \\
0\end{array}$ & $\begin{array}{l}8 \\
8 \\
0 \\
0\end{array}$ & $\begin{array}{l}8 \\
8 \\
0\end{array}$ & $\frac{a}{\partial}$ & $\begin{array}{l}8 \\
8 \\
0\end{array}$ & & & 㐏 & \& & ๕̊ & $\begin{array}{l}8 \\
8 \\
0\end{array}$ & \& \\
\hline $\begin{array}{l}8 \\
\vdots \\
0\end{array}$ & ¿ & $\begin{array}{l}8 \\
\vdots \\
\circ\end{array}$ & $\stackrel{8}{8}$ & & $\approx$ & 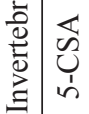 & $\begin{array}{l}8 \\
\vdots \\
0\end{array}$ & @ & $\begin{array}{l}8 \\
\vdots \\
0\end{array}$ & $\begin{array}{l}0 \\
\vdots \\
0 \\
0\end{array}$ & $\begin{array}{l}8 \\
\vdots \\
0\end{array}$ & $\begin{array}{l}8 \\
\vdots \\
0\end{array}$ & $\begin{array}{l}8 \\
\vdots \\
0 \\
0\end{array}$ & $\begin{array}{l}8 \\
\vdots \\
0\end{array}$ & $\begin{array}{l}8 \\
\vdots \\
0\end{array}$ & $\begin{array}{l}8 \\
\vdots \\
0 \\
0\end{array}$ & 号 & 浐 & & $\begin{array}{l}0 \\
0 \\
0 \\
0 \\
\vdots \\
\vdots\end{array}$ & $\begin{array}{l}\mathbb{U} \\
0 \\
\dot{n} \\
i\end{array}$ & $\stackrel{8}{\circ}$ & @̊ & \&̊. & $\stackrel{8}{\circ}$ \\
\hline $\begin{array}{l}\infty \\
\infty \\
0 \\
0\end{array}$ & \&. & $\begin{array}{l}\infty \\
\infty \\
0 \\
0\end{array}$ & ¿े & 号 & & $\vec{Z}$ & $\begin{array}{l}8 \\
8 \\
0 \\
0\end{array}$ & $\begin{array}{l}8 \\
8 \\
0\end{array}$ & \begin{tabular}{|l|}
$\infty$ \\
$\infty$ \\
0 \\
0
\end{tabular} & $\begin{array}{l}0 \\
\vdots \\
0 \\
0\end{array}$ & $\begin{array}{l}0 \\
\stackrel{0}{0} \\
0\end{array}$ & 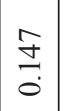 & $\begin{array}{c}0 \\
\stackrel{0}{0} \\
0\end{array}$ & $\begin{array}{l}0 \\
8 \\
0\end{array}$ & $\begin{array}{l}8 \\
8 \\
0\end{array}$ & $\begin{array}{l}8 \\
8 \\
0\end{array}$ & \begin{tabular}{|l|}
$\infty$ \\
0 \\
0 \\
0
\end{tabular} & 守 & 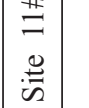 & & $\overrightarrow{\mathrm{Z}}$ & \& & \&̊. & \&̊. & $\frac{5}{9}$ \\
\hline $\begin{array}{l}8 \\
\vdots \\
0\end{array}$ & $\begin{array}{l}8 \\
\vdots \\
\circ\end{array}$ & $\begin{array}{l}\text { tे } \\
\stackrel{0}{\circ}\end{array}$ & : & & & & : & $\begin{array}{l}8 \\
\vdots \\
0\end{array}$ & $\begin{array}{l}8 \\
8 \\
0 \\
\end{array}$ & $\begin{array}{l}8 \\
\vdots \\
0\end{array}$ & $\begin{array}{l}8 \\
\vdots \\
0 \\
0\end{array}$ & $\begin{array}{l}8 \\
\vdots \\
0\end{array}$ & $\begin{array}{l}0 \\
\vdots \\
0 \\
0\end{array}$ & $\begin{array}{l}8 \\
\vdots \\
0\end{array}$ & $\begin{array}{l}8 \\
\vdots \\
\circ\end{array}$ & $\begin{array}{l}8 \\
8 \\
0\end{array}$ & $\begin{array}{l}\tilde{\delta} \\
\dot{0} \\
0\end{array}$ & @̊ & & & 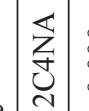 & $\stackrel{8}{\circ}$ & $\stackrel{8}{\circ}$ & $\stackrel{8}{\circ}$ & $\stackrel{8}{\circ}$ \\
\hline $\begin{array}{l}n \\
\vdots \\
0\end{array}$ & $\begin{array}{l}8 \\
\vdots \\
\circ\end{array}$ & $\begin{array}{l}n \\
\vdots \\
0 \\
0\end{array}$ & $\stackrel{8}{\circ}$ & & & $\vec{Z}$ & $\begin{array}{l}8 \\
8 \\
0 \\
0\end{array}$ & $\begin{array}{l}8 \\
\vdots \\
0\end{array}$ & $\begin{array}{l}n \\
0 \\
0 \\
0\end{array}$ & $\begin{array}{l}0 \\
\vdots \\
0 \\
0\end{array}$ & $\begin{array}{l}0 \\
\stackrel{n}{0} \\
0\end{array}$ & $\stackrel{2}{\cong}$ & $\frac{0}{n}$ & $\begin{array}{l}0 \\
\stackrel{0}{0}\end{array}$ & $\begin{array}{l}8 \\
\vdots \\
0\end{array}$ & $\begin{array}{l}8 \\
\vdots \\
0\end{array}$ & $\begin{array}{l}n \\
\hat{0} \\
0 \\
0\end{array}$ & $\stackrel{2}{a}$ & & & 己 & @़ & \& & \& & $\stackrel{2}{\dddot{2}}$ \\
\hline $\begin{array}{l}\infty \\
\vdots \\
0\end{array}$ & $\begin{array}{l}\text { } \\
\dot{0}\end{array}$ & $\begin{array}{l}\stackrel{0}{0} \\
\stackrel{0}{\circ}\end{array}$ & \&े. & & (ృ & 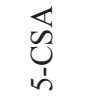 & : & : & $\begin{array}{l}8 \\
\vdots \\
0\end{array}$ & $\begin{array}{l}8 \\
\vdots \\
0 \\
0\end{array}$ & $\begin{array}{l}0 \\
0 \\
0 \\
0\end{array}$ & $\begin{array}{l}8 \\
0 \\
0\end{array}$ & $\begin{array}{l}8 \\
0 \\
0 \\
0\end{array}$ & $\begin{array}{l}\infty \\
\stackrel{0}{0} \\
0\end{array}$ & $\begin{array}{l}8 \\
\vdots \\
0\end{array}$ & $\begin{array}{l}8 \\
\vdots \\
0 \\
0\end{array}$ & 号 & $\begin{array}{l}8 \\
\vdots \\
0\end{array}$ & & v & 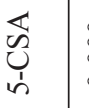 & @ & \& & @ & $\stackrel{8}{\circ}$ \\
\hline ¿. & : & \begin{tabular}{l}
$\infty$ \\
\multirow{8}{0}{} \\
0
\end{tabular} & ¿ & & . & 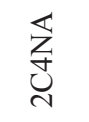 & : & $\begin{array}{l}8 \\
\vdots \\
0\end{array}$ & $\begin{array}{l}8 \\
0 \\
0\end{array}$ & $\begin{array}{l}0 \\
0 \\
0 \\
0\end{array}$ & $\begin{array}{l}8 \\
\vdots \\
0 \\
\end{array}$ & $\begin{array}{l}0 \\
\vdots \\
0\end{array}$ & $\begin{array}{l}0 \\
\vdots \\
0 \\
0\end{array}$ & $\begin{array}{l}0 \\
\vdots \\
0 \\
0\end{array}$ & $\begin{array}{l}0 \\
\vdots \\
0 \\
0\end{array}$ & $\begin{array}{l}8 \\
\vdots \\
0\end{array}$ & $\begin{array}{l}0 \\
\vdots \\
0\end{array}$ & $\begin{array}{l}8 \\
8 \\
0 \\
0\end{array}$ & & 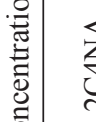 & 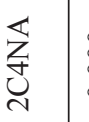 & $\begin{array}{l}8 \\
\vdots \\
0\end{array}$ & @ & @ & : \\
\hline 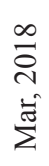 & $\begin{array}{l}\infty \\
\stackrel{\sim}{\circ} \\
\overrightarrow{0} \\
\overrightarrow{4}\end{array}$ & 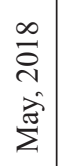 & 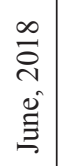 & & & & $\begin{array}{l}\stackrel{ }{\overrightarrow{1}} \\
\stackrel{\curvearrowright}{\Xi}\end{array}$ & 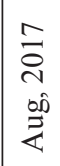 & 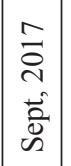 & 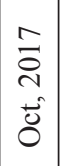 & $\begin{array}{l}\hat{a} \\
\stackrel{n}{1} \\
\vec{a} \\
\stackrel{z}{z}\end{array}$ & 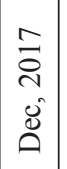 & 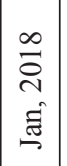 & 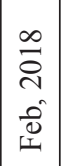 & 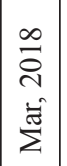 & 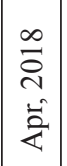 & 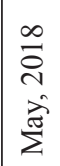 & 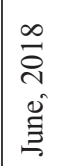 & & & & 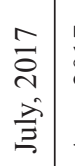 & 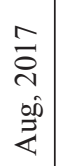 & 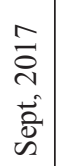 & \\
\hline
\end{tabular}




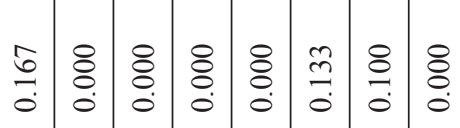

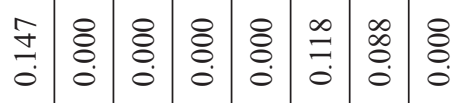

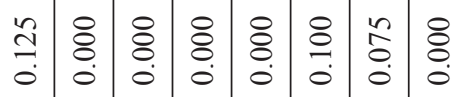

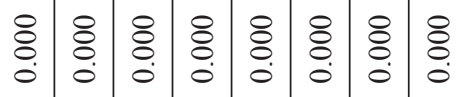

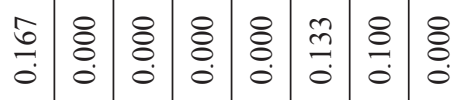

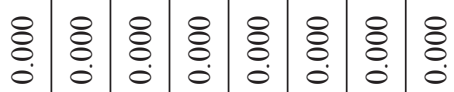

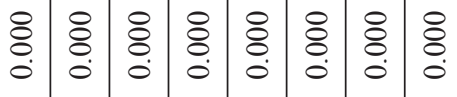

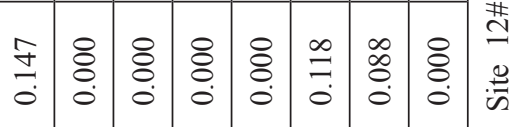

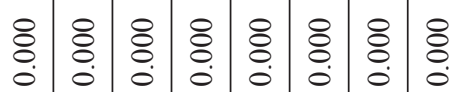

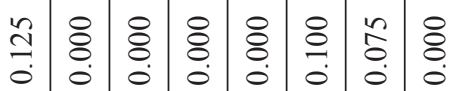

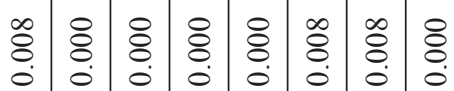

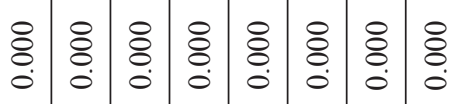

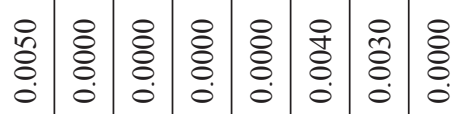

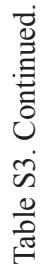

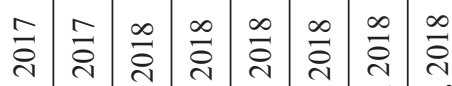
荢

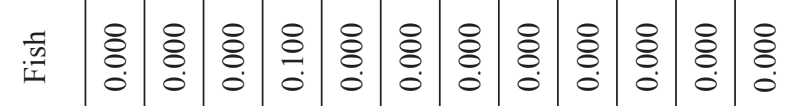

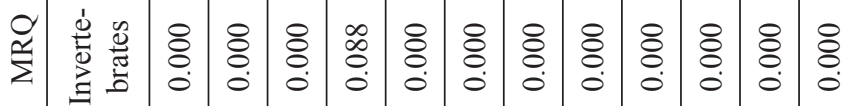

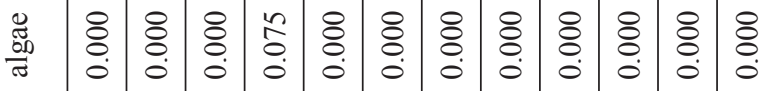

売

需

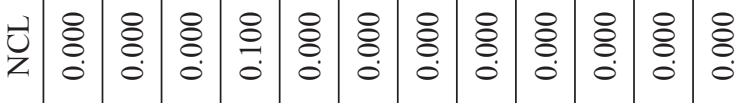

荎

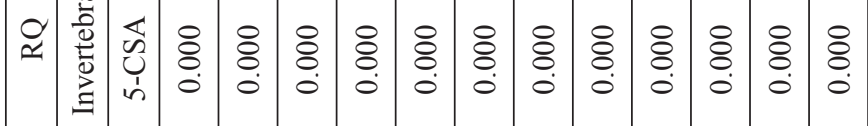

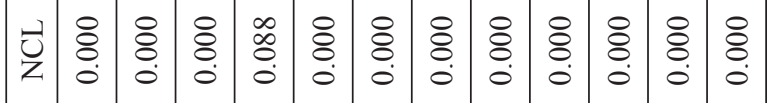

死

荡

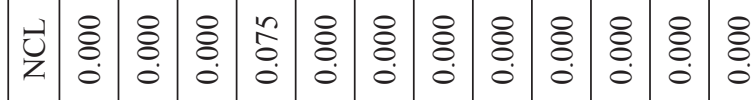

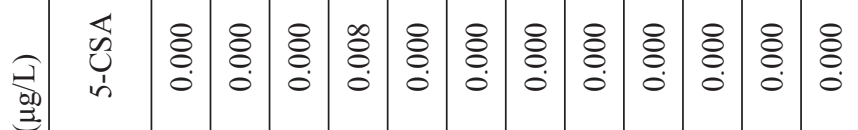

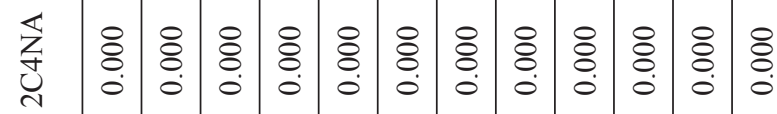

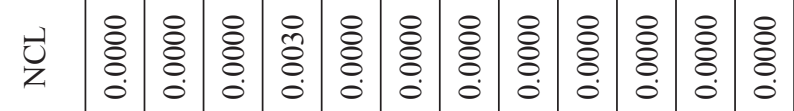

$\stackrel{\Xi}{\Xi}$

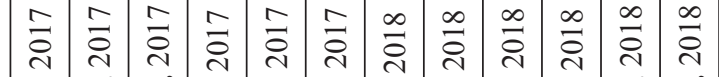

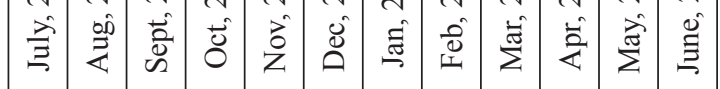



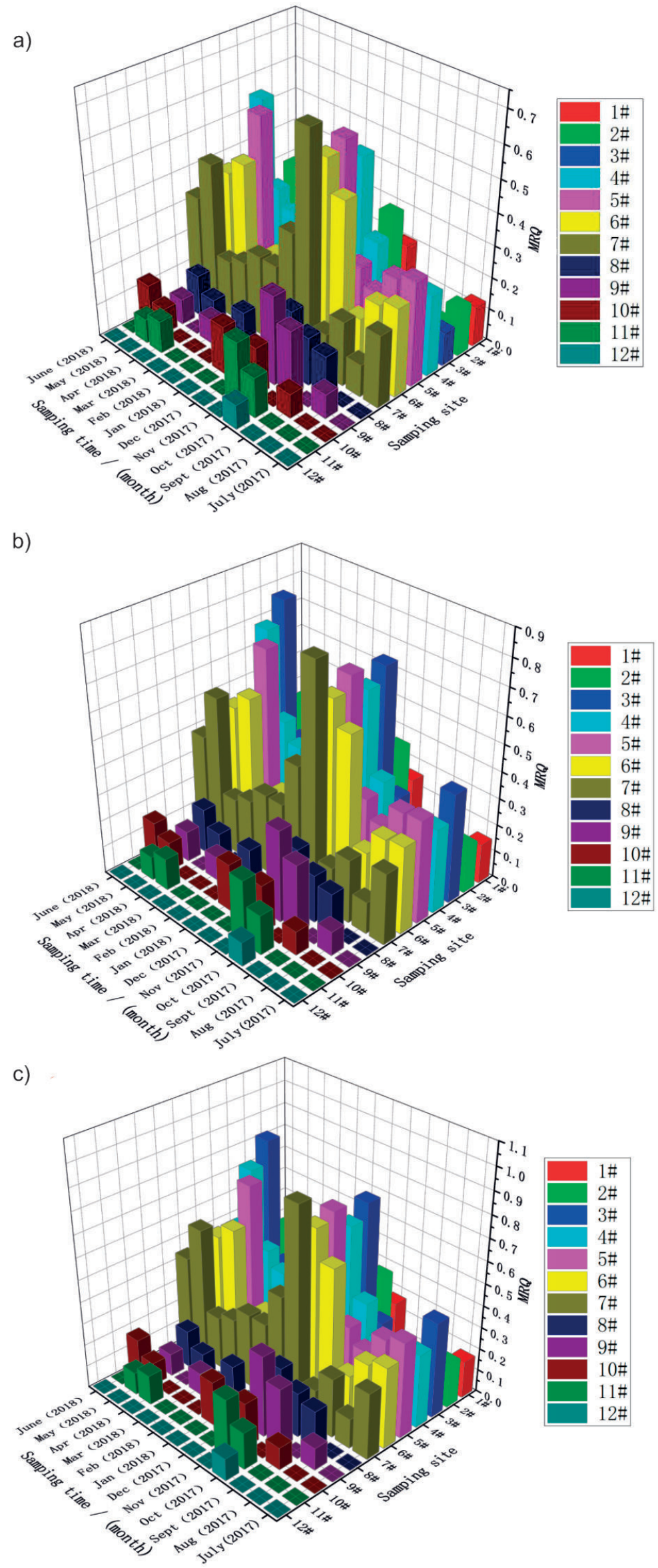

Fig. 5. Calculated mix risk quotients (MRQs) for the detected niclosamide and its degradation intermediate to aquatic organisms: a) algae; b) invertebrates; c) fish. 
Overall, MRQ value of each sampling sites mainly contributed by NCL residue, followed by 2-chloro-4nitroaniline, and 5-chlorosalicylic acid has basically no contribution. The use of NCL has a moderate ecological risk to the lake water in Wucheng waters, but the ecological risk to the river water is low risk.

\section{Conclusions}

This study conducted a one-year sampling analysis of the water environment in Wucheng waters of the Poyang Lake Basin. It was found that due to the use of the molluscicide NCL, the regional water environment contained NCL residues, 2-chloro-4-nitroaniline and 5-chlorosalicylic acid, etc, and their concentrations were $\quad 0.000 \sim 0.028 \mu \mathrm{g} / \mathrm{L}, \quad 0.000 \sim 0.015 \mu \mathrm{g} / \mathrm{L}$, $0.000 \sim 0.019 \mu \mathrm{g} / \mathrm{L}$, respectively. According to the MRQ calculation results, there was a moderate ecological risk in the Wucheng waters, which had certain influence on sensitive aquatic organisms such as algae, invertebrate, and fish in the water environment.

Owing to the lack of long-term monitoring, it is not possible to compare NCL residue levels in different years, under different meteorological and hydrological conditions in the same month. Continuous monitoring is necessary to guide the avoidance of ecological risks caused by making use of niclosamide to control schistosomiasis.

Thus, in the schistosomiasis control area, the problem of the snail-killing agent niclosamide residue pollution should cause the attention of the relevant departments, and more frequent monitoring should be encouraged and focused on lake farming areas to protect the water environment and improve the quality of aquatic products.

\section{Acknowledgements}

We gratefully acknowledge the financial support of the National Natural Science Foundation of China (41363005 and 41967046), the cultivation fund of the key scientific and technical innovation project, Ministry of Education of China (No. 508057).

\section{Conflict of Interest}

The authors declare no conflict of interest.

\section{References}

1. QIU Q.L., CHEN, S.Z., ZUO Y.P., TANG K., DU G.L., HUANG Y.X. Effectiveness of snail control by immersion of molluscicides through tide diversion in marshlands: a field evaluation. Chinese journal of schistosomiasis control, 31 (5), 535, 2019.
2. XIONG T., ZHAO Q.P., XU X.J., LIU R., JIANG M.S., DONG H.F. Morphological and enzymatical observations in Oncomelania hupensis after molluscicide treatment: implication for future molluscicide development. Parasitology Research, 115 (11), 4139, 2016.

3. LI Z.J., GE J., DAI J.R., WEN L.Y., LIN D.D., MADSEN H., ZHOU X.N., LV S. Biology and Control of Snail Intermediate Host of Schistosoma japonicum in The People's Republic of China. Advances in Parasitology, 92, 197, 2016.

4. WANG W.S., ZHANG X., ZHANG H.M., HU H.H., LI S.Z., LIU X., DUAN L.P. Field evaluation of a novel molluscicide (niclosamidate) against Oncomelania hupensis, intermediate host of Schistosoma japonicum. Parasitology Research, 116 (12), 3423, 2017.

5. LIU Y.T., WANG F.H., AI X.H., WANG Z.Y., YANG Q.H., DONG J., XU N. Residue depletion and risk assessment of niclosamide in three species of freshwater fish. Food Additives And Contaminants Part A-Chemistry Analysis Control Exposure \& Risk Assessment, 35 (8), 1497, 2018.

6. XING Y.T., DAI Y., LI Y.Z., JIA Y., LI H.J., QU G.L., WANG W., WEI J.Y., LIANG Y.S., DAI J.R. Distribution of niclosamide spreading oil on water surface and its efficacy against cercariae of schistosoma japonicum. Chinese Journal of Schistosomiasis Control, 24, 410, 2012.

7. PENG X.Z., ZHENG K.E., LIU J., FAN Y.J., TANG C.M., XIONG S.S. Body size-dependent bioaccumulation, tissue distribution, and trophic and maternal transfer of phenolic endocrine, disrupting contaminants in a freshwater ecosystem. Environmental Toxicology and Chemistry, 37 (7), 1811, 2018.

8. Reregistration Eligibility Decision (RED), 3-TrifluoroMethyl-4-Nitro-Phenol and Niclosamide, USEPA, EPA 738-R-99-007; November 1999.

9. MCCONVILLE MEGAN B., MEZYK STEPHEN P., REMUCAL CHRISTINA $\mathrm{K}$. Indirect photodegradation of the lampricides TFM and niclosamide. Environmental science-processes \& impacts, 19( 8), 1028, 2017.

10. SCHULTZ D.P., HARMAN P.D. Hydrolysis and photolysis of the lampricide 2' 5-Dichloro-4'-nitrosalicylanilide (Bayer 73). Invest Fish Control, 85, 1, 1978.

11. MUIR DCG., YARECHEWSKI AL.Degradation of Niclosamide (2',5-Dichloro-4'- nitrosalicylanilide) in Sediment and Water Systems. Journal of Agricultural and Food Chemistry, 30, 1028, 1982.

12. LUO C., HUANG Y.Y., HUANG D.G., LIU M., WEI W., GUO Q., YANG T.Z. Migration and transformation characteristics of niclosamide in a soil-plant system. ACS Omega, 3, 2312, 2018.

13. GRAEBING P.W., CHIB J.S., HUBERT T.D., GINGERICH W.H. Metabolism of niclosamide in sediment and water systems. Journal of Agricultural and Food Chemistry, 52, 5924, 2004.

14. MCCONVILLE M.B., HUBERT T.D., REMUCAL C.K. Direct Photolysis Rates and Transformation Pathways of the Lampricides TFM and Niclosamide in Simulated Sunlight. Environmental science \& technology, 50 (18), 9998, 2016.

15. DORAN G., STEVENS M.M. Simultaneous determination of niclosamide and its degradates in water by LC-MS/MS. Analytical Methods, 6 (17), 6871, 2014.

16. LIU Y.T., AI X.H., WANG F.H., SUO W.W., YANG Q.H., YANG H., XU N. Determination of Niclosamide in Aquatic Animal Tissue by a Novel Extraction Procedure and High-Performance Liquid Chromatography-Heated 
Electrospray Ionization-Tandem Mass Spectrometry. Analytical Letters, 48(6), 929, 2015.

17. EC (European Commission). European Commission Technical Guidance Document in Support of Commission Directive 93//67/EEC on Risk Assessment for New Notified Substances, Commission Regulation (EC) No. 1488/94 on Risk Assessment for Existing Substance and Directive 98/8/EC of the European Parliament and, Part II. 100, 2003.

18. JIN X.Q., JIN M.H., SHENG L.X. Three dimensional quantitative structure-toxicity relationship modeling and prediction of acute toxicity for organic contaminants to algae. Computers in Biology and Medicine, 51, 205, 2014.

19. LI W.M., YIN D.Q., HU S.Q., ZHAI W.Z., WANG L.S. Effects of Two Chloric-Nitroanilines on serum sex steroids in carp (Carassius auratus). Journal of Nanjing University, (Natural Science), 37, 707, 2001.

20. TRABALKA J.R., BURCH M.B. Investigation of the effects of halogenated organic compounds produced in cooling Systems and process effluents on aquatic organisms. Water Chlorination: Environmental Impact and Health Effects, 163, 1978.

21. YANG L.Q., LI H.M., ZHANG Y.Y., JIAO N.Z. Environmental risk assessment of triazine herbicides in the Bohai Sea and the Yellow Sea and their toxicity to phytoplankton at environmental concentrations. Environment International, 133 (Pt A), 135, 2019.

22. GUO J., SELBY K., BOXALL A.B. Assessment of the risks of mixtures of major use veterinary antibiotics in European surface waters. Environmental Science and Technology, 50, 8282, 2016.
23. BACKHAUS T., FAUST M. Predictive environmental risk assessment of chemical mixtures: a conceptual framework. Environmental Science and Technology, 46, 2564, 2012.

24. HERNANDO M.D., MEZCUA M., FERNÁNDEZ-ALBA A.R., BARCELÓ D. Environmental risk assessment of pharmaceutical residues in wastewater effluents, surface waters and sediments. Talanta, 69, 334, 2006.

25. XU W.H., YAN W., LI X.D., ZOU Y.D., CHEN X.X., HUANG W.X., MIAO L., ZHANG R.J., ZHANG G., ZOU S.C. Antibiotics in riverine runoff of the Pearl River Delta and Pearl River Estuary, China: Concentrations, mass loading and ecological risks. Environmental Pollution, 182 (6), 402, 2013.

26. DU J., ZHAO H.X., WANG Y., XIE H.J., ZHU M.H., CHEN J.W. Presence and environmental risk assessment of selected antibiotics in coastal water adjacent to mariculture areas in the Bohai Sea. Ecotoxicology and Environmental Safety, 177, 117, 2019.

27. HALA E., ZAAZAA., MAHA M., ABDELRAHMAN., NOURUDDIN W.ALI., MAIMANA A.M., ABDELKAWY M. Kinetic study and mechanism of Niclosamide degradation. Spectrochimica Acta Part A: Molecular and Biomolecular Spectroscopy, 132, 655, 2014.

28. ANDREWS P., THYSSEN J., LORKE D. The Biology and Toxicology of Molluscicides, Bayluscide. Pharmacology \& Therapeutics, 19, 245, 1983.

29. European Commission- European Chemical Bureau, IUCLID Dataset, 2-chloro-4-nitroaniline, ID: 121-87-9; February 2000. 
